\title{
UK SPORT ORGANIZATIONAL EVOLUTION: GOVERNANCE ASPECTS, OLYMPIC AND PARALYMPIC GAMES INFLUENCE AND INSIGHTS FOR BRAZIL
}

\author{
Carlos Eugenio Zardini Filho \\ Doutorando - Griffith University/AUS \\ Mestre em Gestão do Esporte - Coventry University/ING \\ Gold Coast/AUS. \\ carloszardini@gmail.com
}

\begin{abstract}
Objective: This study analysed the British elite sports agency, UK Sport, offering a detailed look at governance elements and their evolution. Furthermore, some practices from the British agency are compared to actions from the Brazilian public entity SNEAR.
\end{abstract}

Method: A descriptive and exploratory design was used through a case study. The data collection procedure is characterized as documental research.

Relevance: There is a continuous necessity to better understand elite sports systems. From a different angle, organizations frequently shape their structure, approach, and strategies based on "competitors". In the last 50 years, the recent sporting success of UK Sport can be understood as the most relevant regarding elitesports. Moreover, studies involving benchmarking are still incipient in Brazil.

Results: Influenced by the Olympic Games of 2012, UK Sport has rapidly evolved into a more professional organization. Its professional evolution was guided by complementary governance aspects, that is, more and better-qualified staff members, a "business-like" Board composition, a new organizational structure, transparent recruitment processes, more financial resources available, and investments being made through clear strategic goals and criteria. Additionally, the lasting administrations leading UK Sport have provided the necessary stability to implement the changes over the years.

Contributions: The study presented some insights that may help SNEAR to improve its governance practices. Especially, it would be a relevant first step to publish its strategic planning, using as an example UK Sport WCP strategical focus, with no non-Olympic/Paralympic athletes and sports and fewer Olympic/Paralympic athletes and sports being financially supported.

Keywords: UK Sport. SNEAR. Finances. Governance. Strategy.

\section{$\underline{\text { Cite as }}$}

American Psychological Association (APA)

Zardini, C. E. Filho (2020). UK Sport organizational evolution: governance aspects, Olympic and Paralympic Games influence and insights for Brazil. PODIUM Sport, Leisure and Tourism Review, São Paulo, 9(1), 42-70.

https://doi.org/10.5585/podium.v9i1.14429. 


\section{UK SPORT EVOLUÇÃO ORGANIZACIONAL: ASPECTOS DE GOVERNANÇA, INFLUÊNCIA DOS JOGOS OLÍMPICOS E PARALÍMPICOS E INSIGHTS PARA O BRASIL}

\section{Resumo}

Objetivo: Este estudo analisou a agência britânica de esporte alto desempenho, UK Sport, oferecendo uma visão detalhada de elementos de governança e sua evolução. Ademais, algumas práticas da agência britânica são comparadas com ações da entidade pública brasileira SNEAR.

Método: Utilizou-se um design descritivo e exploratório por meio de um estudo de caso. O procedimento de coleta de dados é caracterizado como pesquisa documental.

Relevância: Há uma necessidade contínua de se entender melhor os sistemas esportivos de alto rendimento. Em outro prisma, organizações frequentemente moldam suas estruturas, abordagems e estratégias baseando-se em "concorrentes". Nos últimos 50 anos, o recente sucesso esportivo do UK Sport pode ser entendido como o mais relevante referente a esportes de elite. Além disso, estudos envolvendo benchmarking ainda são incipientes no Brasil.

Resultados: Influenciado pelos Jogos Olímpicos de 2012, a UK Sport evoluiu rapidamente se tornando uma organização mais profissional. Sua evolução profissional foi guiada por aspectos complementares de governança, ou seja, mais e melhor qualificados funcionários, uma composição de Conselho mais "empresarial", uma nova estrutura organizacional, processos transparentes de recrutamento, mais recursos financeiros disponíveis e investimentos sendo feitos através de metas e critérios estratégicos. Ademais, as administrações duradouras que lideraram a UK Sport forneceram a estabilidade necessária para se implementar mudanças ao longo dos anos.

Contribuições: O estudo apresentou algumas idéias que podem ajudar a SNEAR a melhorar suas práticas de governança. Especialmente, um primeiro passo relevante seria publicar seu planejamento estratégico, usando como exemplo o foco estratégico do WCP da UK Sport, sem atletas e esportes não-Olímpicos/Paraolímpicos e menos atletas e esportes Olímpicos/Paraolímpicos recebendo apoio financeiro.

Palavras-chave: UK Sport. SNEAR. Finanças. Governança. Estratégia.

\section{Introduction}

The management of sports has gradually evolved in the last decades (Sarmento \& Carvalho, 2015), in which the mega-events have a significant role in this evolution (Green \& Houlihan, 2005). Moreover, in the last twenty years, a process of legitimisation of political aspects has been supporting efforts to fund and develop elite athletes (Green, 2004). Generally, these investments aim to achieve good results in international sporting events, international prestige, national pride and economic development (Houlihan \& Green, 2008; Mazzei, Meira, Bastos, Böhme \& De Bosscher, 2015), in which a state may assume regulatory and supervisory roles on sports systems (Sarmento \& Carvalho, 2015). Furthermore, Soares, Antunes, Bárbara, Escórcio and Saldanha (2016) argue that there is 
academic evidence underpinning public investments in elite sports, claiming a positive return to the economy and state (taxes). According to Theodoraki (1999), the pressure on governments to promote sporting success is irreversible. In countries such as Spain, the UK and Japan, there has been a substantial increase in public funding allocated to elite sport, which does not reflect a similar proportionate increase in the total sports budget (Houlihan \& Zheng, 2013). In this context, countries have been creating specific public organizations to develop elite sports.

Currently, researchers and managers are engaged in explaining the reasons behind the success achieved by countries in terms of high-performance sports. Certainly, taking elite sports as a system, and their development as the result of effective policies, the analysis of different countries can be considered a strategic action (Mazzei et al., 2015). In addition, authors such as Houlihan (2009), Legg et al. (2015), De Bosscher et al. (2008; 2015) and Dowling et al. (2017) demonstrated that there is a continuous necessity to better understand elite sports systems. Therefore, studies on how elite-sports systems, policies, and organizations work in different countries have been receiving increased attention from researchers worldwide.

From a different angle, organizations frequently shape their structure, approach, and strategies based on other "competitors". Concepts such as isomorphism (DiMaggio \& Powell, 1983; Caemmerer \& Marck, 2009) and benchmarking (Nascimento, 2017; Jardim, 2011a; Jardim 2011b) illustrate how some companies appropriate best practices from other organizations. However, it is often unclear under what conditions best practices may work in other contexts or structures (De Bosscher et al., 2015).

Hantrais (1999) stated that cross-national research (comparative) has as an objective to identify the similarities and differences between countries to gain a better awareness and a deeper insight into a research subject across different national contexts. Likewise, Dowling et al. (2017) claim that comparisons of elite-sports systems should answer questions such as what makes some nations more successful at international competitions than others, and what is the most efficient and effective way to develop high-performance athletes. Furthermore, according to Mazzei et al. (2015), research on sport public policies is usually conducted using a comparative basis of structures and actions in different countries. In this scenario, comparisons of sports organizations are usually conducted, in which countries and researchers attempt to better understand strategies, policies, and practices to better learn from the experiences of other countries.

Influenced by the opportunity of hosting the Olympic and Paralympic Games and their potential sporting legacies, countries such as Brazil have massively invested in elite sports policies. In fact, due to the Rio 2016 Games, the Brazilian government has stipulated the objective of becoming a worldwide sporting power (Castro, Poffo \& Souza, 2016). Based on this goal, an analysis of best practices from successful "competitors" may offer new insights and parameters to the Brazilian government and main actors involved in the national sports policy. For instance, the Brazilian sports authorities could observe other countries in terms of strategies and how their policies were impacted by the Olympic Games.

Specifically, about Brazil, other points justify why the country should further study its own policy and policies from other countries to improve its international sporting results. For example, Mazzei et al. (2015) pointed out that, until a few years ago, there was not a considerable number of studies about the development of high-performance sports in Brazil. Additionally, there has been a lack of studies related to the necessary organizational structure in Brazil regarding national elite sports based on international specialized literature (Meira, Bastos \& Böhme, 2012; Mazzei et al., 2015). Other authors also draw attention to the need for 
more research on the issue of the development of high-performance sport in Brazil (Meira \& Bastos, 2011), including about funding processes (Castro, Poffo \& Souza 2016). Likewise, little is known about the Brazilian government administrative structure in favour of elite sports (Mendes \& Codato, 2015). Moreover, studies involving benchmarking are still incipient in Brazil (Jardin, 2011b).

For a long time, national sporting organizations in Brazil have been relying on public funding to develop their sports initiatives, but cases of misuse of these resources are frequently reported by the press. For instance, in 2019, national federations were not legally able to receive public funding because of unapproved accountability processes (Vecchioli, 2019a). Due to this necessity of sports managers to improve the management of organizations in Brazil and a similar necessity of more studies around best practices that may offer insights to Brazil to obtain better sporting results, this article provides a deep analysis of the British case. Undoubtedly, the United Kingdom's (UK) recent sporting success can be understood as the most relevant in the last 50 years. After all, the country came from a $36^{\text {th }}$ medal ranking position (9 medals) in 1996 Atlanta Olympic Games to a second position in the Rio 2016 edition (67 medals), becoming a "sporting superpower" (Ahmed, Leahy \& Pearson, 2016; UOL, 2004). Furthermore, the European country was the host of the Olympic and Paralympic Games in 2012.

In summary, this study aims to analyse the British high-performance sports agency, UK Sport, offering a detailed look at governance elements and their professional evolution, which may reveal new approaches, practices, and strategies for Brazil. Furthermore, some practices from the British agency are compared to actions put in place by the Brazilian public entity responsible for elite sports in the country.

\section{Method}

This research was structured based on a descriptive and exploratory design. Descriptive research has as its objective to obtain information around something that already exists, to describe and interpret the reality, without any interference in it (Rubio, 1999). On the other hand, exploratory studies are typically conducted to satisfy the researcher's curiosity and desire for better understandings of a specific phenomenon (Babbie, 2007), when the subject is less explored, and as the first step to deeper investigations (Gil, 1999).

The research design focuses on a case study. Yin (1984) states that case studies are aligned with exploratory methods, as they aim to explore a phenomenon in a specific dataset. Moreover, in areas such as government and management, case studies methods are extensively used (Zainal, 2007). In addition, Eisenhardt (1989) defines a case study as a research strategy that focuses on understanding the dynamics present within single settings, which help to explain both the process and outcome of a phenomenon (Zainal, 2007). In other words, it examines experiences or actions without separating them from the context in which they occurred (Harris \& Houlihan, 2016). Palmer et al. (2018) summarized that a case study may not only assist in finding which outcomes were produced from interventions but also how they were produced and in which contextual conditions.

In order to visualize the British evolution related to its elite sports policy, the UK Sport was the entity chosen for this analysis. The sampling process to select the UK Sport as the case study of this research is featured as a theoretical one, which selects cases suitable for illuminating and extending relationships and logic among constructs, being selected for nonstatistical reasons (Eisenhardt \& Graebner, 2007). UK Sport, founded in 1996, was set up to create pathways into sports and eventually into sporting success at the elite level, with the aim

PODIUM Sport, Leisure and Tourism Review | São Paulo | v. 9 | n. 1 | p. 42-70 | Jan./Apr. 2020 
to compete and win medals at both the Olympic Games and the Paralympic Games. Therefore, UK Sport is focused upon elite sport over community and school sports sectors, mainly, through the World Class Programme (WCP). Precisely, UK Sport invests National Lottery and Exchequer income into Olympic and Paralympic sports (UK Sport, 2016b; UK Sport, 2016c).

Some authors demonstrate that case studies may collect data from distinct sources, such as interviews, questionnaires (qualitative or quantitative surveys), reports, documents, and participatory observations (Vimarlund \& Keller, 2014; Eisenhardt, 1989; Paudel, 2009). In this study, the data collection procedure is characterized as documental research (e.g.: official reports). Mogalakwe (2006) claims that documentary research is sometimes more cost-effective than surveys, interviews, or participant observation. The same author also states that the use of documentary methods refers to the analysis of documents (e.g., official/public documents) that contain information about the phenomenon targeted in the study.

The data collection and analysis processes were divided into three macro steps related to governance, that is, human resources, organizational structure, and finances. Priority was given to official documents from UK Sport, with other documents (such as media reports) being observed when no official information was found. The data analysis also followed the suggestions of Henry et al. (2005), that is, comparative sports policy studies can seek similarities, describe differences, or theorize transnational phenomena. It is worth mentioning that the classic work of Green and Oakley (2001) also provided a lens to observe elite sports systems and organizations, in terms of "diminishing contrasts" and "increasing varieties".

After the analysis of the practices of UK Sport, some comparisons were discussed observing the British case and the organization in Brazil that would have similar responsibilities and roles in the country. However, some authors assess that there is no straightforward or perfect model for comparing high-performance sports (Dowling et al., 2017). In fact, the appropriate methods and tools to compare are still controversial (Lodge, 2007). For instance, too many variables in comparisons can be dangerous, which can create meaningless similarities and differences (Dowling et al., 2017).

\section{Results}

\subsection{Political and Governance contexts}

Before the analysis of UK Sport, it is important to understand the political context that affected the organization. Firstly, from the near past, Thatcher's era has affected the British sports through its political and ideological ideas, which has changed the whole nation. In general, the new policies changed the governance of public and private sports entities. For example, Thatcher's government created the Compulsory Competitive Tendering (CCT) that led to the "marketisation of the sport", that is, services that were previously provided by local governments (including sports) were exposed to free competition, in an attempt to obtain more financial efficiency to the public services (Bramham, Hylton, Nesti \& Jackson, 2001; Robinson, 2004). After the end of Thatcher's era, in 1990, the British state implemented policies to modernize itself and improve its capacity to deliver public services. A turning point for the development of sports in the UK was the creation of the National Lottery in 1993, in which part of the revenue from the Lottery would support sporting initiatives (Bramham et al. 2001). This, therefore, returns to the state the essential role of investing public funds in sports.

PODIUM Sport, Leisure and Tourism Review | São Paulo | v. 9 | n. 1 | p. 42-70 | Jan./Apr. 2020 
In 1997, with a Labour government in charge, the CCT was replaced by the Best Value policy, that is, some services would be mandatorily public. The new policy meant a new strategic approach, in which sports were seen as an important social tool that required continuous public improvements (Bramham et al., 2001; Robinson, 2004). Furthermore, the new Labour government has started a process of modernization of public institutions (Houlihan \& Green, 2009). In this context, UK Sport was created by a Royal Charter in 1996 and implemented in 1997 (DCMS, 2015a), as a non-departmental public body/NDPB (Houlihan \& Green, 2009). Nowadays, the organisation is known as the nation's highperformance sports agency, investing in Olympic and Paralympic sports and being accountable to the Department for Culture, Media and Sport - DCMS (UK Sport, 2015a).

However, in its beginning, UK Sport was criticized for a lack of clear objectives and organizational rationale (Houlihan \& Green, 2009). Additionally, the organization was facing public criticisms such as from the House of Commons' Committee of Public Accounts, which questioned the governance method and the results of UK Sport (Houlihan \& Green, 2009). Under those circumstances, the organization was submitted to a modernization process that has changed some key elements of its governance structure. The first and most important step was the appointment in 2003 of Sue Campbell as the Chairman. This step resulted in new directors, culling of staff, internal restructuring, clarification of objectives, and a new business plan (Houlihan \& Green, 2009). Although with a new executive team, the organization was still coping with demands to improve its internal control and funding system (National Audit Office, 2005). In addition, in 2006 the British sports agency had its governance demands substantially increased, because UK Sport assumed full responsibility for all Olympic and Paralympic performance-related support in the UK (UK Sport, 2006a). Simultaneously, the country obtained the right to host the Olympic and Paralympic Games in 2012, which has given legitimacy to the process of professionalization of the organization (Houlihan \& Green, 2009). As a result, the organization had to face new governance challenges to evolve and to match the new public expectation around the sporting performance of the country.

In terms of governance, recently a broad debate around it in sports took place, mainly due to an ongoing process of professionalization of sports institutions worldwide (Ferkins, McDonald \& Shilbury, 2010), which included UK Sport. According to Tricker (1984), governance regards the creation, use, and limitation of powers to direct, control, and regulate activities within an organisation. In public and non-profit settings, governance is described in terms of stakeholder representation and stewardship of the organisation resources (Herman and Renz, 2000). In line with Ferkins, Mcdonald, and Shilbury (2010), policies, operations, and board performance are key elements of governance. Next, the evolution of the professionalization of UK Sport is observed based on these governance aspects, focusing on human resources, organizational structure, and finances practices.

\subsection{Professional evolution}

In the last decade, UK Sport has built a clear strategy, which is basically to work through partnerships to develop elite sports in the UK, aiming at world-class success (DCMS, 2015b). However, when London was chosen as the host of the 2012 Olympics and Paralympics Games, UK Sport started to face major structural changes and new objectives were defined (Houlihan \& Green, 2009), forcing the entity to an evolution process. Below, based on Bayle and Robinson (2007) and Ferkins, Mcdonald, and Shilbury (2010), the professional evolution of UK Sport is observed in terms of permanent staff members, internal structure, and the executive Board.

PODIUM Sport, Leisure and Tourism Review | São Paulo | v. 9 | n. 1 | p. 42-70 | Jan./Apr. 2020 


\subsection{1 $\underline{\text { Staff }}$}

Analysing the UK Sport annual reports since 2000, it is possible to visualize that the number of full-time employees has more than doubled since 2000/01. Consequently, the necessary annual cost has increased as well, achieving a figure almost 7 times bigger than the expenses from 2000. The following table illustrates the increased numbers of staff members.

Table 1 - Evolution of number and costs of staff members in the UK Sport, from 2001 to 2019

\begin{tabular}{|c|c|c|c|c|c|c|c|c|c|c|c|c|c|c|}
\hline Years & 2001 & 03 & 05 & 07 & 08 & 09 & 10 & 12 & 13 & 15 & 16 & 17 & 18 & 2019 \\
\hline $\begin{array}{c}\text { Staff } \\
\text { members }\end{array}$ & 50 & 84 & 79 & 83 & 94 & 84 & 89 & 92 & 98 & 103 & 102 & 108 & 114 & 121 \\
$\begin{array}{c}\text { Costs - } \\
\text { millions }\end{array}$ & $£ 1,5$ & $£ 3,3$ & $£ 4,0$ & $£ 4,3$ & $£ 5,6$ & $£ 4,9$ & $£ 5,3$ & $£ 5,6$ & $£ 6,3$ & $£ 6,7$ & $£ 7.6$ & $£ 7.9$ & $£ 9.8$ & $£ 10.2$ \\
\hline
\end{tabular}

Sources: UK Sport (2001a; 2001b; 2002a; 2002b; 2003a; 2003b; 2004a; 2004b; 2005a; 2005b; 2007; 2008; 2009; 2010; 2011a; 2012a; 2013; 2014; 2015a; 2017a; 2016b; 2017b; 2018; 2019c).

Furthermore, still based on the UK Sports annual reports, the level of turnover related to the Chairman and CEO positions is significantly low, which could have helped the institution to better create, implement and monitor initiatives of professionalization/modernization. The following table presents the names and the respective years when a new professional was appointed as CEO or Chairman of UK Sport.

Table 2 - Chairman and CEO changes in UK Sport history

\begin{tabular}{|c|c|c|c|}
\hline \multicolumn{2}{|c|}{ Chairman } & \multicolumn{2}{c|}{ CEO } \\
\hline Name & Took over in: & Name & Took over in: \\
\hline Rodney Walker & 1998 & Richard Callicott & 1999 \\
\hline Sue Campbell & 2003 & Liz Nicholl & 2003 \\
\hline Rod Carr & 2013 & John Steele & 2005 \\
\hline \multirow{2}{*}{ Dame Grainger } & \multirow{2}{*}{2017} & Liz Nicholl & 2010 \\
\cline { 2 - 4 } & & Sally Munday & 2019 \\
\hline
\end{tabular}

Sources: UK Sport (2001a; 2001b; 2002a; 2002b; 2003a; 2003b; 2004a; 2004b; 2005a; 2005b; 2007; 2008; 2009; 2010; 2011a; 2012a; 2013; 2014; 2015a; 2017a; 2016b; 2017b; 2018; 2019c).

Equally important, analysing the news available on UK Sport official website, from 2001 to 2019 (UK Sport, 2016a; 2019a), it is possible to observe that new managers were hired having relevant previous experiences in both sports and executive positions. Undoubtedly, the knowledge and expertise brought by them were crucial to enhance the level of professionalism of the organization, which may have helped the UK to achieve the successful results in the London and Rio Olympic Games. Below, Table 3 shows important positions of the organization, the year when a new professional started in a specific position and their previous professional background.

Table 3 - Main replacements in UK Sport until 2016

\begin{tabular}{|c|l|c|c|}
\hline Name & \multicolumn{1}{|c|}{ Main previous background before working at UK Sport } & New Position & Year \\
\hline Peter Keen & British Cycling Performance Director & Performance Adviser & 2004 \\
\hline John Steele & $\begin{array}{l}\text { Executive Director at the Northampton Saints Rugby } \\
\text { Football Club }\end{array}$ & $\begin{array}{c}\text { Chief Executive } \\
\text { Officer }\end{array}$ & 2005 \\
\hline $\begin{array}{c}\text { Tim } \\
\text { Hollingsworth }\end{array}$ & Granada Media and the Confederation of British Industry & $\begin{array}{c}\text { Director of Policy } \\
\text { and Communications }\end{array}$ & 2005 \\
\hline
\end{tabular}




\begin{tabular}{|c|l|c|c|}
\hline $\begin{array}{c}\text { Simon Le } \\
\text { Fevre }\end{array}$ & $\begin{array}{l}\text { Executive Deputy Director at the United Nations } \\
\text { Association of Great Britain and Northern Ireland }\end{array}$ & Head of Operations & 2006 \\
\hline $\begin{array}{c}\text { Vanessa } \\
\text { Wilson }\end{array}$ & $\begin{array}{l}\text { Head of Strategic Communications, Campaigns and } \\
\text { Marketing at the Department for Environment, Food and } \\
\text { Rural Affairs (Defra); and Head of the Strategic } \\
\text { Communications Planning Unit at the Department for } \\
\text { Education and Skills }\end{array}$ & $\begin{array}{c}\text { Director of } \\
\text { Commercial and } \\
\text { Communications }\end{array}$ & 2011 \\
\hline $\begin{array}{c}\text { Simon } \\
\text { Timson }\end{array}$ & $\begin{array}{l}\text { England and Wales Cricket Board (ECB) as Head of the } \\
\text { England Development Programme and Science and } \\
\text { Medicine }\end{array}$ & $\begin{array}{c}\text { Director of } \\
\text { Performance }\end{array}$ & 2012 \\
\hline Chelsea Warr & $\begin{array}{l}\text { Elite Development Manager at the Queensland Academy } \\
\text { of Sport; and GB Athlete Identification and Development } \\
\text { Manager at the British Swimming }\end{array}$ & $\begin{array}{c}\text { Director of } \\
\text { Performance }\end{array}$ & 2016 \\
\hline
\end{tabular}

Sources: UK Sport (2004c; 2005c; 2006b; 2011b; 2012b; 2019b); Scottish Disability Sport (2016); Linkedin (2019); BBC (2020).

According to DCMS (2015a; 2015b), the professional level of the chosen main managers of UK Sport has been positively accepted by the sporting community. This approval can be seen by the fact that the National Governing Bodies/NGBs evaluated UK Sport giving a positive rating of approximately $82 \%$ in terms of supporting elite (DCMS, 2015a). It is worth noticing that UK Sport has a special approach towards NGBs, having an in-house team to support them, which provides experiences and expertise to help British NGBs to improve their governance (UK Sport, 2015a; 2015b).

Due to the UK Sport modernization process, more qualified professionals have been required, affecting the recruitment of staff members (Houlihan \& Green, 2009). This factor created, for example, a new emphasis on requesting business techniques for key supporting roles (Houlihan \& Green, 2009). As a consequence, the UK Sport recruitment strategy does not offer evidence of being politically driven. The UK Sport website and other documents from the organization also leads to the conclusion that the company's HR recruitment practices have been a mix of internal and external sources. For instance, all vacancies are advertised internally with the selection of candidates being supported by defined criteria (DCMS, 2015b). Analysing the top executive positions through the official website (UK Sport, 2015d; 2019b), it is possible to observe that most of these positions were occupied by staff members that had previously worked at the organisation for a relevant period, therefore, suggesting an efficient process of internal recruitment. UK Sport has also implemented a specific platform on its official website publicly showing the vacancies available, explaining the process of selection and the mandatory requirements to apply for a position at the organization (UK Sport, 2015e; 2015g). This recruitment policy demonstrates a commitment to equal opportunities and transparency. Likewise, it aims to select professionals only based on their abilities and merits (DCMS, 2015b), creating a more professional and impartial process.

From a complementary angle, a specific policy supported by the Equality Standard has been implemented in UK Sport (Sracklen, Hylton \& Long, 2006), which has generated some positive results. For instance, analysing the composition of the five main executive positions in 2015, three of them (including the CEO) were occupied by women (UK Sport, 2015d), which implies a certain level of diversity between the genders. The same tendency has happened with the positions available for technical panels, where $51 \%$ of the seats were occupied by women in 2015 (UK Sport, 2015f). In 2019, UK Sport had 55\% of its staff members and 7 out of 10 Board members being women (UK Sport, 2019c). However, some facts show that improvements are still necessary. For example, in the composition of the Board in 2015 , only $10 \%$ of it corresponded to black professionals or from minority groups 
(DCMS, 2015a). In addition, in the same year, less than 5\% of UK Sport staff was black. In 2018 and 2019, only $13 \%$ of the staff members were Black or belonging to a minority group (UK Sport, 2018; 2019c). Furthermore, in 2019 only 20\% of the UK Sport workforce were between 45-65 years, with no staff member being over 65 years old (UK Sport, 2019c). Therefore, the entity should continuously work to be more diverse and better represent the people affected by its actions (DCMS, 2015a), enhancing its experiences and social backgrounds. It is worth noticing that no information was found about the current number of people with disabilities working at UK Sport (UK Sport, 2019c).

\subsubsection{Internal structure}

In 1999/2000 the executive team of UK Sport was composed of the CEO and five more directors. This structure was changed in 2003/2004, when the organization lost two directors. Nevertheless, from 2006, more significant changes have been implemented, mainly in 2008/09, with the new positions of Chief Operating Officer and Finance Director being implemented in the organization. In 2009/10, all the anti-doping activities of UK Sport were transferred to a new entity, the UK Anti-Doping, which resulted in one less department (UK Sport, 2010). Certainly, that new internal structure could demonstrate the attempt to modernize the organization before the London 2012 Games. Table 4 presents the main changes until 2020. Given the proximity of the Olympic and Paralympic Games of 2012, also supported by the debate around the Olympic legacy, the organization changed its internal structure again in 2012, with other changes happening after the Olympic Games in London (DCMS, 2015a; 2015b). The new departmental structure illustrates the attempt of UK Sport to adapt the organization to a new reality after the London Games, having its internal configuration decreased but still aiming at keeping a similar level of organizational efficiency.

Table 4 - Main executive structural changes in UK Sport from 2006 to 2020

\begin{tabular}{|c|c|c|c|c|c|}
\hline 2006/07 & 2008/09 & $2011 / 12$ & $2014 / 2015$ & $2015 / 2016$ & 2020 \\
\hline $\mathrm{CEO}$ & $\mathrm{CEO}$ & $\mathrm{CEO}$ & CEO & CEO & $\mathrm{CEO}$ \\
\hline $\begin{array}{l}\text { Director of } \\
\text { Elite Sport }\end{array}$ & $\begin{array}{c}\text { Chief Operating } \\
\text { Officer }\end{array}$ & $\begin{array}{c}\text { Chief Operating } \\
\text { Officer }\end{array}$ & $\begin{array}{c}\text { Chief Operating } \\
\text { Officer }\end{array}$ & $\begin{array}{c}\text { Chief } \\
\text { Operating } \\
\text { Officer }\end{array}$ & $\begin{array}{c}\text { Chief Operating } \\
\text { Officer }\end{array}$ \\
\hline $\begin{array}{l}\text { Director of } \\
\text { Drug-Free } \\
\text { Sport and } \\
\text { International }\end{array}$ & $\begin{array}{l}\text { Performance } \\
\text { Director }\end{array}$ & $\begin{array}{l}\text { Director of } \\
\text { Performance }\end{array}$ & $\begin{array}{c}\text { Director of } \\
\text { Performance }\end{array}$ & $\begin{array}{c}\text { Director of } \\
\text { Performance }\end{array}$ & $\begin{array}{l}\text { Director of } \\
\text { Performance }\end{array}$ \\
\hline $\begin{array}{l}\text { Director of } \\
\text { Corporate } \\
\text { Services }\end{array}$ & Finance Director & Finance Director & $\begin{array}{c}\text { Director of } \\
\text { Finance, } \\
\text { Investment and } \\
\text { Business } \\
\text { Services } \\
\end{array}$ & $\begin{array}{c}\text { Director of } \\
\text { Finance, } \\
\text { Investment and } \\
\text { Business } \\
\text { Services } \\
\end{array}$ & $\begin{array}{c}\text { Director of } \\
\text { Finance, } \\
\text { Investment and } \\
\text { Business } \\
\text { Services } \\
\end{array}$ \\
\hline \multirow[t]{2}{*}{$\begin{array}{c}\text { Director of } \\
\text { Policy and } \\
\text { Communica- } \\
\text { tions }\end{array}$} & $\begin{array}{c}\text { Director of } \\
\text { Drug-Free Sport }\end{array}$ & $\begin{array}{c}\text { Director of } \\
\text { Corporate } \\
\text { Development }\end{array}$ & $\begin{array}{c}\text { Director of } \\
\text { Major Events } \\
\text { and International } \\
\text { Relations }\end{array}$ & $\begin{array}{c}\text { Director of } \\
\text { Commercial \& } \\
\text { Communica- } \\
\text { tions }\end{array}$ & $\begin{array}{c}\text { Director of } \\
\text { Communications } \\
\text { and Partnerships }\end{array}$ \\
\hline & $\begin{array}{l}\text { Director of } \\
\text { Business } \\
\text { Support }\end{array}$ & $\begin{array}{c}\text { International } \\
\text { Development } \\
\text { Director and } \\
\text { International } \\
\text { Inspiration } \\
\text { Programme } \\
\text { Director } \\
\end{array}$ & $\begin{array}{c}\text { Director of } \\
\text { Commercial \& } \\
\text { Communications }\end{array}$ & & \\
\hline
\end{tabular}




\begin{tabular}{|c|c|c|l|l|l|}
\hline & $\begin{array}{c}\text { Director of } \\
\text { Policy and } \\
\text { Communications }\end{array}$ & $\begin{array}{c}\text { Director of } \\
\text { Major Events } \\
\text { and International } \\
\text { Relations }\end{array}$ & & & \\
\hline & Head of & & & \\
International & Development \\
and International & Director of \\
Inspiration & Communications \\
and Commercial & & & & \\
& Programme & & & & \\
Director & & & & \\
\hline
\end{tabular}

Sources: UK Sport (2007; 2009; 2012a; 2015a; 2016b; 2020).

In 14 years (from 2006 to 2020), Table 4 shows a considerable number of structural changes, but areas such as investment, business services, and communications have recently received special attention in the organization structure. Especially from 2014, subjects such as investments, business services, partnerships, and communications have been part of the UK Sport core structure, which makes clear its professional evolution over the years.

Since 2011, the commercial practices of the entity have been gaining more importance. Certainly, commercial initiatives in public entities have some natural limitations. However, even this sort of organization can create commercial value to attract partners and accomplish its mission. In fact, strategic partnerships with private organizations were built to improve UK Sport capacity to deliver elite sports development. For example, in 2011, the department of Commercial, Communications and Public Affairs was created (UK Sport, 2011a), which would be responsible for attracting and working with partners to leverage commercial opportunities and sponsorships from the private sector (UK Sport, 2012a). In a joint venture with the British Olympic Association, British Paralympic Association and with the London Organising Committee for the 2012 Games, the department was partially responsible for the Visa sponsorship agreement (UK Sport, 2012a), which generated an income of $£ 10 \mathrm{~m}$ in 2012 (UK Sport, 2010).

Moreover, facing a necessity to assist the NGB's in terms of specialized knowledge in science and technology, and aiming at achieving a better level of professional capacity, the English Institute of Sport (EIS) was founded in 2002 as a subsidiary of UK Sport (UK Sport, 2015c). The EIS, which in 2019 employed 381 staff members (UK Sport, 2019c), provides a wide range of professional services, with most of the income coming from the NGBs (in a commercial relationship). It is worth noticing that a significant part of the NGBs revenues come from the National Lottery, mainly through the WCP that is managed by UK Sport itself (DCMS, 2015a). Until 2015, the EIS obtained on average $£ 6.9$ million annually, however, in 2019 the EIS income reached $£ 28$ million (UK Sport, 2019c).

\subsubsection{UK Sport Board}

According to UK Sport (2012a), the Board members are appointed by the Secretary of State, being formed by the Chair and nine members, consisting of five independent members and four representatives of the Home Nation Sports Councils. Furthermore, its main role is described by a Royal Charter, that is, to provide strategic direction to UK Sport (DCMS, 2015a). Over the years, the Board faced pressure to evolve itself, for instance, in 2018 a new Code for Sports Governance implemented that (1) at least $30 \%$ of each gender would be part of it, (2) the Board would be the ultimate decision-making authority within a sport, and (3) tighter term limits (UK Sport, 2018). Additionally, two Observers were implemented in the 
structure of the Board, the Chair of the EIS, and the Head of Sport of DCMS (UK Sport, 2018).

The Board changes demonstrate how UK Sport attempted to evolve towards a more professional and modern organization. Houlihan and Green (2009) claimed that, due to this modernization process, UK Sport started to allocate more professional staff members through the Board's routines of audit and inspections. Based on the same authors, the organization has also replaced Board representatives looking for new members with more business skills/experiences, which may have helped to transform UK Sport into a more 'business-like' organization.

Since 2004, there have been panels composed by members of the Board to perform specific analysis, with these panels receiving more autonomy and strategic roles (UK Sport 2004a; 2004b; 2018). In 2014, there were three groups of panels (remuneration, audit, and major events), which supported the Board in their strategic decision-making processes (UK Sport 2014; 2015h). More recently, the Board has been receiving support from other advisory bodies, such as the Audit Committee, to perform the Board responsibilities around issues of risk, control, and governance (UK Sport, 2018). The Board meets every two months (UK Sport, 2015a, 2018) to consider and make decisions on recommendations put forward by the executive team of UK Sport or from the panels of the Board itself (DCMS, 2015a; 2015b).

\subsection{Finance management}

For a long time, public organizations have been facing pressure in terms of how they manage their financial resources (Cavalcanti \& Santana, 2014). Certainly, the financial situation of a public entity may create governance and management challenges that require planning and fast adaptations. In the following section, some points of UK Sport financial health, strategy, and expenses are analysed.

\subsubsection{Evolution of the UK Sport financial resources}

UK Sport has basically two different main sources of revenue: direct investments from the government (Exchequer/Grants) and from the National Lottery. These sources are used to (1) support athletes; (2) support sport partners (e.g.: NGB's), mainly through the WCP; and (3) maintain itself (UK Sport, 2016b, 2016c). The resources from the National Lottery are managed through the National Lottery Distribution Fund (NLDF) that is under the responsibility of the Secretary of State for Culture, Olympics, Media and Sport (UK Sport, 2014; 2015a). UK Sport takes the resources from the fund when a payment or an investment is necessary (Zardini Filho et al., 2017).

Table 5 compares the Lottery and Grant-in-Aid funding streams for UK Sport. Based on the numbers, there is no apparent trend in the Grant funding history. In the Chinese and British Olympic cycles, there were more Grants for the Olympic years and in the year before them, followed by a decrease after the Games. This trend was not repeated during the Rio 2016 cycle. However, over the past twenty years, there has been a substantial increase in direct governmental funding (from $£ 12 \mathrm{~m}$ to $£ 70 \mathrm{~m}$ ), providing almost 6 times more public (direct) resources to UK Sport. A significant increase was seen in 2005/06, with an enhancement of $81.21 \%$, which could be attributed to London winning the bid to host the 2012 Olympics. The total amount of resources from the National Lottery also increased, achieving an approximate $400 \%$ from 1999 to 2018 . Moreover, there were only two occasions

PODIUM Sport, Leisure and Tourism Review | São Paulo | v. 9 | n. 1 | p. $42-70$ | Jan./Apr. 2020 
when both financial sources have decreased at the same time, 2002/03 and 2013/14, years after the Olympic Games.

Table 5 - Comparison of funding streams: Lottery and Grant-in-Aid

\begin{tabular}{|c|c|c|c|c|c|}
\hline $\begin{array}{l}\text { Financial } \\
\text { Year }\end{array}$ & $\begin{array}{l}\text { Lottery Funding } \\
\text { (in millions) }\end{array}$ & $\begin{array}{c}\% \\
\text { increase/decrease } \\
\text { on the previous } \\
\text { year }\end{array}$ & $\begin{array}{l}\text { DCMS } \\
\text { Funding - } \\
\text { "Grant-in-Aid" } \\
\text { (in millions) }\end{array}$ & $\begin{array}{c}\% \\
\text { increase/decrease } \\
\text { on the previous } \\
\text { year }\end{array}$ & $\begin{array}{c}\text { Relevance of the } \\
\text { year }\end{array}$ \\
\hline $1999 / 2000$ & $£ 18.778$ & - & $£ 12.327$ & - & \\
\hline $2000 / 01$ & $£ 23,735$ & $26.40 \%$ & $£ 12.452$ & $1.01 \%$ & Sydney Olympics \\
\hline $2001 / 02$ & $£ 25.442$ & $7.19 \%$ & $£ 16.381$ & $31.55 \%$ & \\
\hline $2002 / 03$ & $£ 21.110$ & $-17.03 \%$ & $£ 15.513$ & $-5.30 \%$ & \\
\hline $2003 / 04$ & $£ 19.927$ & $-5.60 \%$ & $£ 23.018$ & $48.38 \%$ & \\
\hline $2004 / 05$ & $£ 20.798$ & $4.37 \%$ & $£ 23.089$ & $0.31 \%$ & Athens Olympics \\
\hline $2005 / 06$ & $£ 21.198$ & $1.92 \%$ & $£ 29.305$ & $26.92 \%$ & $\begin{array}{c}\text { London won the } \\
2012 \text { bid }\end{array}$ \\
\hline $2006 / 07$ & $£ 53.277$ & $151.33 \%$ & $£ 53.105$ & $81.21 \%$ & \\
\hline $2007 / 08$ & $£ 45.716$ & $-14.20 \%$ & $£ 67.380$ & $26.89 \%$ & \\
\hline $2008 / 09$ & $£ 47.452$ & $3.80 \%$ & $£ 72.201$ & $7.15 \%$ & Beijing Olympics \\
\hline $2009 / 10$ & $£ 56.259$ & $18.56 \%$ & $£ 59.645$ & $-17.39 \%$ & \\
\hline $2010 / 11$ & $£ 58.761$ & $4.45 \%$ & $£ 55.363$ & $-7.18 \%$ & \\
\hline $2011 / 12$ & $£ 69.550$ & $18.36 \%$ & $£ 60.651$ & $9.55 \%$ & \\
\hline $2012 / 13$ & $£ 88.298$ & $26.96 \%$ & $£ 65.966$ & $8.76 \%$ & London Olympics \\
\hline $2013 / 14$ & $£ 75.704$ & $-14.27 \%$ & $£ 43.020$ & $-34.78 \%$ & \\
\hline $2014 / 15$ & $£ 82.223$ & $8.61 \%$ & $£ 49.452$ & $14.95 \%$ & \\
\hline $2015 / 16$ & $£ 87.705$ & $6.6 \%$ & $£ 38.583$ & $-21.9 \%$ & \\
\hline $2016 / 17$ & $£ 74.325$ & $-15.5 \%$ & $£ 53.536$ & $38.7 \%$ & Rio Olympics \\
\hline $2017 / 18$ & $£ 74.560$ & $0.31 \%$ & $£ 61.957$ & $15.7 \%$ & \\
\hline $2018 / 19$ & $£ 72.961$ & $-2.14 \%$ & $£ 70.091$ & $13.12 \%$ & \\
\hline \multicolumn{2}{|c|}{ Overall \% Increase } & $388.55 \%$ & & $568.60 \%$ & \\
\hline
\end{tabular}

Source: Zardini Filho et al. (2017) and UK Sport (2016b, 2017b, 2018, 2019c).

The increment of resources available for UK Sport, certainly influenced by the London Games, has required more attention on the investment strategy, which demanded transparency and governmental and public accountability (DCMS, 2015a; 2015b).

\section{$\underline{\text { 3.3.2 }} \underline{\text { Strategic investment }}$}

After some criticism about the lack of strategic vision, objectives, and investments at its beginning (Houlihan \& Green, 2009) and having an enhanced public investment, nowadays UK Sport has a clearer strategy to support NGB's. This strategy focuses on sports and athletes with a real chance of obtaining a medal in major international competitions, investing only in athletes directly nominated by their Olympic or Paralympic NGB (UK Sport, 2015h). In summary, the financial resources agreed between UK Sport and a specific NGB, for an Olympic/Paralympic cycle, would depend on goals previously planned by the parties, in which the results achieved during the partnership would define an increase, reduction or even a total break of the financial aid (Mackay, 2015; Roan, 2017).

Despite good sporting results being achieved, the UK Sport funding strategy is still facing criticism, mainly after resources being cut for some sports, for example sports that failed to meet their targets for London 2012 (Mackay, 2015). Under these circumstances, UK 
Sport has decided to change some criteria after the Rio 2016 cycle, such as (1) including the observation of participation rates and (2) investments being made in an eight-year cycle (Mackay, 2015). Certainly, these changes will increase administrative challenges for UK Sport and create new planning challenges for the NGBs. However, for the Tokyo cycle (20162020), the UK Sport strategic plan continues to focus on medals in major international competitions (UK Sport, 2017b). In this way, it is investing more in sports with higher potential to win medals in Olympic and Paralympic Games. According to De Bosscher et al. (2015), there is a strong relationship between financial resources available and international sporting success, which supports the UK Sport strategy.

From 2006, UK Sport has become responsible for all British performance funding programs, that is, the UK participation and investments towards Sydney and Athens Games were not exclusively supported and planned by UK Sport (UK Sport, 2017b). Due to this concentration of responsibilities and considering the 2012 Games in London, a significant jump in terms of resources available for UK Sport is noticed from 2006 (Table 5). Undoubtedly, this increment of resources also meant an increment of resources for the NGB's. Tables 6 and 7 present the numbers regarding investment in sports during Summer Olympic and Paralympic cycles.

Table 6 - UK Sport investments per sports during Olympic cycles, in millions of pounds

\begin{tabular}{|c|c|c|c|c|c|}
\hline $\begin{array}{l}\text { Summer } \\
\text { Olympics }\end{array}$ & 2000 & 2004 & 2008 & 2012 & 2016 \\
\hline Sports & Sydney & Athens & Beijing & London & Rio de Janeiro \\
\hline Archery & $£ 0$ & $£ 0.800$ & $£ 2.834$ & $£ 4.408$ & $£ 2.952$ \\
\hline Athletics & $£ 10.600$ & $£ 11.400$ & $£ 26.513$ & $£ 25.148$ & $£ 26.824$ \\
\hline Badminton & $£ 0,00$ & $£ 0,00$ & $£ 8.759$ & $£ 7.434$ & $£ 5.737$ \\
\hline Basketball & $£ 0,00$ & $£ 0,00$ & $£ 3.694$ & $£ 8.599$ & $£ 0$ \\
\hline Boxing & $£ 0,00$ & $£ 0,00$ & $£ 5.005$ & $£ 9.551$ & $£ 13.764$ \\
\hline Canoeing & $£ 4.500$ & $£ 4.700$ & $£ 13.622$ & $£ 16.176$ & $£ 20.043$ \\
\hline Cycling & $£ 5.400$ & $£ 8.600$ & $£ 22.151$ & $£ 26.032$ & $£ 30.267$ \\
\hline Diving & $£ 0.900$ & $£ 1.400$ & $£ 5.873$ & $£ 6.535$ & $£ 7.467$ \\
\hline Equestrian & $£ 3.000$ & $£ 4.400$ & $£ 11.727$ & $£ 13.395$ & $£ 17.992$ \\
\hline Fencing & $£ 0$ & $£ 0$ & $£ 3.074$ & $£ 2.529$ & $£ 4.225$ \\
\hline Gymnastics & $£ 5.900$ & $£ 4.100$ & $£ 9.036$ & $£ 10.770$ & $£ 14.615$ \\
\hline Handball & $£ 0$ & $£ 0$ & $£ 2.986$ & $£ 2.924$ & $£ 0$ \\
\hline Hockey & $£ 0$ & $£ 0$ & $£ 9.882$ & $£ 15.013$ & $£ 16.141$ \\
\hline Judo & $£ 3.900$ & $£ 4.100$ & $£ 6.947$ & $£ 7.498$ & $£ 7.366$ \\
\hline $\begin{array}{c}\text { Modern } \\
\text { Pentathlon }\end{array}$ & $£ 1.100$ & $£ 2.000$ & $£ 5.920$ & $£ 6.288$ & $£ 6.972$ \\
\hline Rowing & $£ 9.600$ & $£ 10.600$ & $£ 26.042$ & $£ 27.287$ & $£ 32.622$ \\
\hline Sailing & $£ 5.100$ & $£ 7.600$ & $£ 22.292$ & $£ 22.292$ & $£ 25.504$ \\
\hline Shooting & $£ 0$ & $£ 1.400$ & $£ 5.056$ & $£ 2.461$ & $£ 3.950$ \\
\hline Swimming & $£ 6.900$ & $£ 6.400$ & $£ 20.659$ & $£ 25.144$ & $£ 20.795$ \\
\hline $\begin{array}{l}\text { Synchronised } \\
\text { Swimming }\end{array}$ & $£ 0,00$ & $£ 0,00$ & $£ 1.648$ & $£ 3.398$ & $£ 0,00$ \\
\hline Table Tennis & $£ 0,00$ & $£ 0,00$ & $£ 2.533$ & $£ 1.213$ & $£ 0,00$ \\
\hline Taekwondo & $£ 0.600$ & $£ 0.600$ & $£ 2.667$ & $£ 4.833$ & $£ 8.052$ \\
\hline Triathlon & $£ 1.400$ & $£ 2.600$ & $£ 5.113$ & $£ 5.291$ & $£ 7.457$ \\
\hline Volleyball & $£ 0$ & $£ 0$ & $£ 4.112$ & $£ 3.536$ & $£ 0$ \\
\hline Water Polo & $£ 0$ & $£ 0$ & $£ 3.147$ & $£ 2.928$ & $£ 0$ \\
\hline Weightlifting & $£ 0$ & $£ 0.300$ & $£ 1.686$ & $£ 1.365$ & $£ 1.709$ \\
\hline Wrestling & $£ 0$ & $£ 0$ & $£ 2.125$ & $£ 1.435$ & $£ 0$ \\
\hline Total & $£ 58.900 .000,00$ & $£ 71.000 .000,00$ & $£ 235.103 .000,00$ & $£ 263.493 .753,00$ & $£ 274.464 .541,00$ \\
\hline
\end{tabular}

Source: UK Sport (2017c). 
Table 7 - UK Sport investments per sports during Paralympic cycles, in millions of pounds

\begin{tabular}{c|c|c|c|c|c|}
$\begin{array}{c}\text { Summer } \\
\text { Paralympics }\end{array}$ & 2000 & 2004 & 2008 & 2016 \\
Sports & Sydney & Athens & Beijing & London & $\begin{array}{c}\text { Rio de } \\
\text { Janeiro }\end{array}$ \\
\hline Boccia & $£ 0.112$ & $£ 0.229$ & $£ 0.614$ & $£ 2.333$ & $£ 3.663$ \\
\hline Football & $£ 0$ & $£ 0$ & $£ 0.170$ & $£ 0$ & $£ 0$ \\
\hline Shooting & $£ 0.138$ & $£ 0.245$ & $£ 0.576$ & $£ 2.085$ & $£ 3.407$ \\
\hline Table Tennis & $£ 0.272$ & $£ 0.401$ & $£ 0.909$ & $£ 1.699$ & $£ 3.006$ \\
\hline Goalball & $£ 0.162$ & $£ 0.017$ & $£ 0.115$ & $£ 0.513$ & $£ 0$ \\
\hline Archery & $£ 0$ & $£ 0.531$ & $£ 1.212$ & $£ 2.147$ & $£ 2.449$ \\
\hline Athletics & $£ 3.725$ & $£ 3.286$ & $£ 5.454$ & $£ 6.730$ & $£ 10.837$ \\
\hline Canoe & $£ 0$ & $£ 0$ & $£ 0$ & $£ 0$ & $£ 3.048$ \\
\hline Cycling & $£ 0$ & $£ 0.516$ & $£ 1.761$ & $£ 4.198$ & $£ 6.833$ \\
\hline Equestrian & $£ 0$ & $£ 1.188$ & $£ 2.404$ & $£ 3.605$ & $£ 3.782$ \\
\hline Rowing & $£ 0$ & $£ 0$ & $£ 1.303$ & $£ 2.332$ & $£ 3.834$ \\
\hline Sailing & $£ 0$ & $£ 0$ & $£ 1.228$ & $£ 1.748$ & $£ 3.616$ \\
\hline Swimming & $£ 3.523$ & $£ 4.445$ & $£ 6.925$ & $£ 10.468$ & $£ 11.756$ \\
\hline Triathlon & $£ 0$ & $£ 0$ & $£ 0$ & $£ 0$ & $£ 3.100$ \\
\hline Powerlifting & $£ 0.151$ & $£ 0.339$ & $£ 0.691$ & $£ 1.092$ & $£ 0.891$ \\
\hline Sitting Volleyball & $£ 0$ & $£ 0$ & $£ 0.230$ & $£ 0.786$ & $£ 0$ \\
\hline Judo & $£ 0$ & $£ 0.648$ & $£ 0.725$ & $£ 1.294$ & $£ 2.019$ \\
\hline W. Basketball & $£ 1.636$ & $£ 1.835$ & $£ 3.099$ & $£ 4.493$ & $£ 5.379$ \\
\hline W. Fencing & $£ 0.076$ & $£ 0.100$ & $£ 0.340$ & $£ 0.552$ & $£ 0.194$ \\
\hline W. Rugby & $£ 0.223$ & $£ 0.564$ & $£ 0.979$ & $£ 2.361$ & $£ 3.037$ \\
\hline W. Tennis & $£ 0.054$ & $£ 0.473$ & $£ 0.803$ & $£ 0.809$ & $£ 1.925$ \\
\hline Total & $£ 10.075 .602,00$ & $£ 14.821 .355,00$ & $£ 29.545 .872,00$ & $£ 49.254 .386,00$ & $£ 72.786 .654,00$ \\
\hline
\end{tabular}
Source: UK Sport (2017c).

From the abovementioned tables, two facts are worth noticing. First, the Summer Olympic sports were responsible for $83.65 \%$ of the amount invested by UK Sport (£902.961.294,00). Second, after the Rio 2016 Games, the total investment since 2000 exceeds 1 billion pounds ( $£ 1.079 .445 .163,00$ ). During Rio 2016, the five sports that had the best performances for the Great Britain Team (in terms of medals achieved) were cycling (12 medals), athletics (7), gymnastics (7), swimming (6) and rowing (5) (BBC Sport, 2016). Observing the data from Table 6, all of them were within the top 10 most funded sports during the Brazilian cycle. Since 2008, the cycle when UK Sport was fully responsible for the British preparation, these sports have also been within the top 10 most funded sports. The following figure illustrates this funding trend. Certainly, this fact underpins the UK Sport long-term investment strategy in specific sports with better chances of winning medals. 
Figure 1 - The evolution of the resources delivered by UK Sport to the top 10 most funded sports, from the cycles of Beijing to Rio

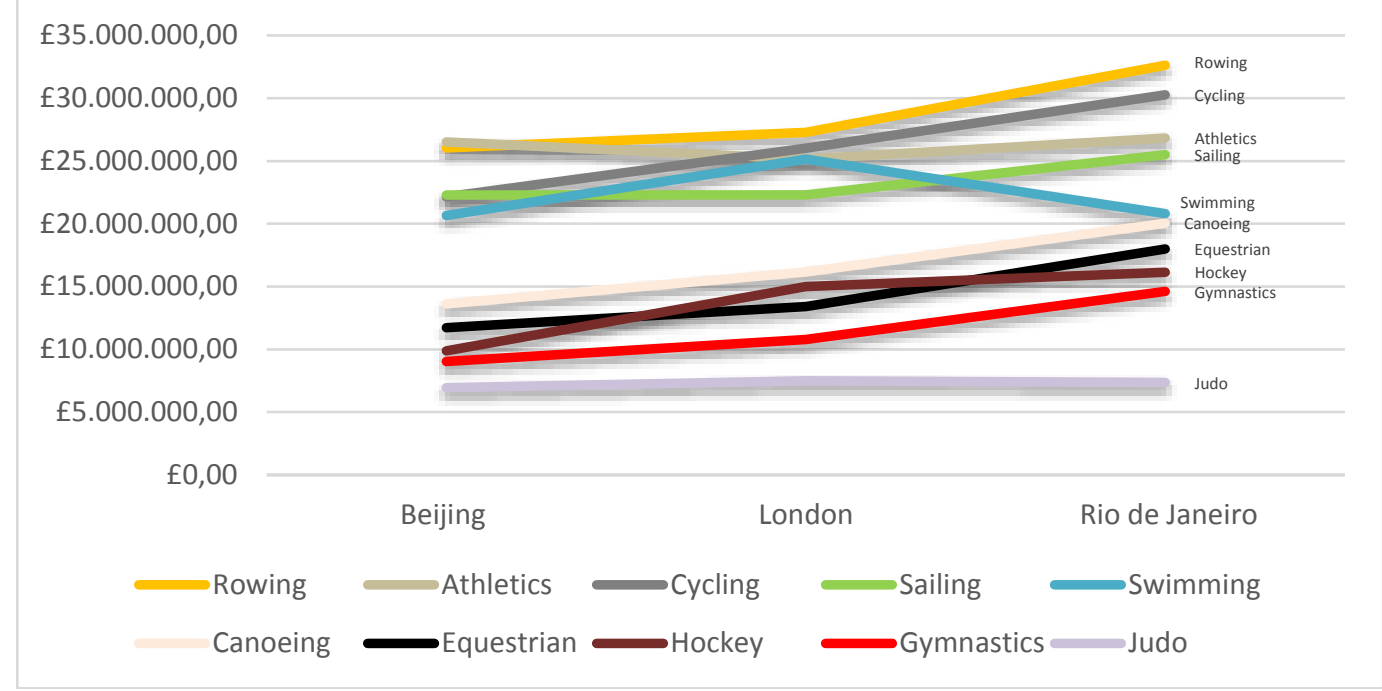

Source: UK Sport (2017b; 2017c).

In summary, the professional evolution of UK Sport focused on complementary aspects related to its governance, that is, more and better-qualified staff members, "businesslike" Board composition and orientation, more diverse staff members, new organizational structure, more financial resources available and investments being made through a clear strategic goal and criteria. As a result, since the foundation of UK Sport, the British performance in Olympic Games jumped from a 36th medal ranking position in Atlanta 1996 to second place in Rio 2016 (Ahmed, Leahy \& Pearson, 2016; UOL, 2004).

\section{Discussion}

\subsection{Comparisons with the national elite-sports public organization in Brazil}

Having seen key points of the UK Sport organizational evolution, it seems natural to compare these points with other countries, such as Brazil. For this purpose, the National High-Performance Sport Secretariat/SNEAR, part of the federal government of Brazil, was chosen to be compared in terms of governance and management practices. In fact, both organizations have similar roles and responsibilities in their countries. The Brazilian entity is responsible for coordinating, elaborating and implementing public policies for highperformance sports in the country, aiming at preparing athletes to represent Brazil in international competitions (Silva, Borges \& Amaral, 2015). Nowadays, SNEAR is linked to the Ministry of Citizenship of Brazil/MC. Certainly, considering the legal systems of the countries and the nature of the organizations, a direct comparison between UK Sport and SNEAR has clear limitations.

Financial comparisons are not made in this study. After all, it is well known that there is a huge economic difference between Brazil and the UK. Moreover, it is also clear that international sporting success is largely determined by socioeconomic factors (Mazzei et al., 2015; De Bosscher et al., 2008). Therefore, the comparisons made in this paper have indeed clear limitations. Nevertheless, the British case clearly offers insights in terms of governance, strategies, and practices for Brazil, including strategic use of public resources. 
Firstly, it is essential to observe the recent context that has been shaping the actions of SNEAR. Before and after the Rio 2016 Olympic and Paralympic Games, Brazilian sports authorities have been facing public criticisms around the national elite-sport policy. For instance, the Federal Court of Accounts/TCU (2011) claimed that three years after being chosen as Olympic host for 2016 the former Brazilian Ministry of Sport/ME had no strategic planning detailing the national high-performance sport policy. The same entity also affirmed that the sports organization had structural and operational issues that put at risk the governmental objective of turning Brazil into a sporting superpower nation (TCU, 2011). Moreover, iconic Brazilian athletes have said that the country needed to re-build its policy, insofar as only financial resources would not be capable of creating successful sporting nations (Silva, 2015a).

SNEAR also faces challenges regarding the current governance issues of Brazilian NGBs. For instance, in 2019, five Olympic national federations were not legally able to receive public funding due to unapproved accountability reports or due to the lack of mandatory documents related to the NGBs fiscal status (Vecchioli, 2019a). Furthermore, the country has been for decades facing a financial and political crisis, which impacted on elite sports policies and investments (Costa, 2019; Vecchioli, 2019b; 2019c; 2019d; 2019e; 2019f; 2019g).

From a different angle, little is known about the elite sports administrative structure of the Brazilian government (Mendes \& Codato, 2015). Additionally, some authors pointed out that the country has been investing a relevant amount of public resources on elite sports, however, there has been a lack of strategic planning and integration of policies to better define a national strategy aiming at international sporting success (Soares et al., 2016). Below, Table 8 presents a non-exhaustive comparison of key points related to UK Sports evolution and practices, discussed above, against some initiates of SNEAR.

Table 8 - Key UK Sport evolution aspect $v s$ structure and practices of SNEAR

\begin{tabular}{|c|c|}
\hline UK Sport & SNEAR \\
\hline $\begin{array}{l}\text { a) The Board provides strategic direction. } \\
\text { Members with business skills/experiences. }\end{array}$ & $\begin{array}{l}\text { There is an institutional National Sports Council / } \\
\text { CNE, with limited powers, linked to the MC. The }\end{array}$ \\
\hline $\begin{array}{l}\text { b) Board panels: acting on subjects such as } \\
\text { remuneration and audit. }\end{array}$ & $\begin{array}{l}\text { inactive. Members with no business skills } \\
\text { requirement. }\end{array}$ \\
\hline $\begin{array}{l}\text { c) The published business plan focuses on } \\
\text { sporting and managerial results. }\end{array}$ & $\begin{array}{l}\text { There is no published strategic planning or } \\
\text { business plan. }\end{array}$ \\
\hline $\begin{array}{l}\text { d) Commercial practices looking for private } \\
\text { resources and partnerships. }\end{array}$ & There are no commercial practices at any level. \\
\hline $\begin{array}{l}\text { e) Only four changes in the highest position of } \\
\text { the organization in a period of twenty years. }\end{array}$ & $\begin{array}{l}\text { In seventeen years, there were ten different } \\
\text { people as National Secretary. }\end{array}$ \\
\hline $\begin{array}{l}\text { f) Recruitment strategy: more business and } \\
\text { sport-oriented profiles. Opened recruitment } \\
\text { processes. Increasing number of full-time staff } \\
\text { members. }\end{array}$ & $\begin{array}{l}\text { One public selection/recruitment for civil servants } \\
\text { in the last fifteen years. Lack of sports specialists } \\
\text { and business professionals. Political-based } \\
\text { selections for no-civil servant positions, } \\
\text { traditionally fulfilled based on personal } \\
\text { relationships, with no sports/business experiences } \\
\text { required. }\end{array}$ \\
\hline $\begin{array}{l}\text { g) WCP strategy focuses on mega-events results, } \\
\text { guided by clear criteria and objectives, and } \\
\text { agreed on formal agreements. }\end{array}$ & $\begin{array}{l}\text { There is a legal instrument called Performance } \\
\text { Contract with NGB's, which would have clear } \\
\text { goals and sporting strategic planning. However, } \\
\text { this instrument has been waiting for regulation } \\
\text { since } 2011 \text {. }\end{array}$ \\
\hline
\end{tabular}


h) NGB's are funded based on the UK Sport sporting goals, only supporting Olympic and Paralympic sports.

i) EIS provides scientific support to NGB's.

j) Women frequently being positioned in top positions.

k) Overall, UK Sport directly acts to provide professional "consultancy" to NGB's, offering support and expertise to help them to improve their governance.

Sources: Mazzei et al. (2015), Agência Estado (2007), Alvarez (2011), Cruz (2015), Estadão (2015, 2020), Folha Online (2003), Globo Esporte (2016), iG São Paulo (2015), Jorge (2016), ME (2017a, 2017b, 2016, 2011, 2017c, 2017d, 2017e, 2013, 2007), Pereira (2015), Portal da Transparência (2017a, 2017b, 2017c, 2017d), Pussieldi (2016), Redação Pragmatismo (2015), Silva (2015a), Terra (2017), Vecchioli (2017), SNEAR (2019, 2020), SEE (2020a, 2020b, 2020c), JusBrasil (2019).

Certainly, the observations related to SNEAR need deeper analysis. Nevertheless, it is already clear that governance elements show evidence that the Brazilian organization needs to improve its governance practices. In addition, it is also clear that there is a distance between the organizations in terms of Board guidance, transparent strategies, and criteria to develop elite sports. For example, regarding the observations from "a" to " $\mathrm{k}$ " in Table 8, and still based on the same sources, it is possible to conclude that:

"a" and "b": There is no clear evidence about a general process of accountability from SNEAR to CNE, neither a strategic guidance from the Council to SNEAR (exception made about a pre-defined percentage of direct grants for some non-Olympic athletes). Furthermore, SNEAR does not have a specific elite sports Board or Council, or even an in-house technical panel, to support its strategic and political decisions. Based on the CNE website, only one out of six CNE's commissions are currently active. All these facts illustrate a lack of technical and strategic guidance to support the decision-making processes of SNEAR. Certainly, the UK Sport Board business and sporting skills have helped the institution to evolve, offering an example that could be useful to SNEAR;

"c": Taking into account the SNEAR website, the organization does not have a strategic planning or business plan, or they were not published on the official website. This fact raises concerns around a lack of strategic guidance in terms of governance and financial investments on NGBs; which nowadays is one of the most valuable aspects of UK Sport;

"e": Observing tables 8 and 9 (below), several different actors have led SNEAR since 2003. Apart from the former Secretary Ricardo Leyser (responsible for the organization during approximate seven years), the other nine managers had on average one year as leader of SNEAR. In contrast, Sue Campbell was UK Sport Chairman for ten years, with the following two other managers in that position stayed there for more than four years each. The lasting periods under the administrations of the same managers clearly helped the modernization process of UK Sport, shaping its current level of expertise. Even taking into account that the 
top SNEAR position is politically selected, the responsible authorities for this selection could use the British case to re-think their future choices.

Table 9 - SNEAR Secretaries since 2003

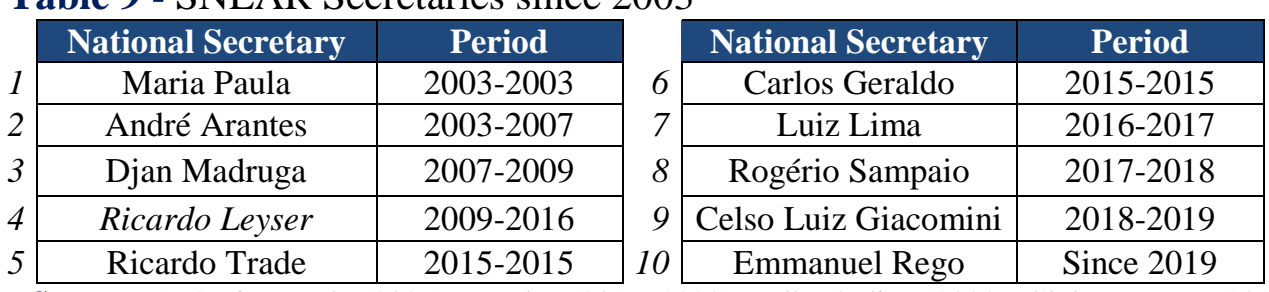

Sources: Agência Estado (2007), Estadão (2015, 2020), Folha Online (2003), Globo Esporte (2016), iG São Paulo (2015), Jorge (2016), Pussieldi (2016), Silva (2015b), Terra (2017), Globo Esporte (2019), SNEAR (2019, 2020), SEE (2020a, 2020b, 2020c), JusBrasil (2019).

SNEAR also demonstrates issues of organizational structure, specifically in terms of human resources (Mendes \& Colada, 2015). For instance, in 2017, the year after the Rio Games, the public organization had 105 people in its workforce but only eleven of them were permanent civil servants able to legally perform sports analysis in funding processes to support NGB's (CGU, 2017). Other eight civil servants were originally from other Ministries, working in temporary assignments, performing sports technical and bureaucratic roles (CGU, 2017). Furthermore, in a partnership with a Federal Bank, SNEAR temporally had eleven engineers to specifically analyse infrastructure projects related to the Rio 2016 Olympic Games (CGU, 2017). Therefore, most of the SNEAR workforce was performing bureaucratic roles. In particular, 65 of them were outsourced staff members (temporary contracts) (CGU, 2017), with political influences on their recruitment and non-legally qualified to perform analysis of funding to sports projects. Based on CGU (2017), the lack of permanent civil servants performing technical analysis in SNEAR has created a scenario of outsourced staff members performing this role.

In the same 2017, SNEAR obtained a budget of almost 160 million Brazilian Reais for investments in sports (ME, 2018), with a payroll of approximate 6 million Brazilian Reais (CGU, 2017). On the other side, UK Sport had in 2017/18 approximate 135 million pounds (around 680 million Brazilian Reais) to invest in elite sports and in its maintenance (UK Sport, 2018), with 108 available full-time staff members. Moreover, UK Sport has a clear strategy of concentrating most of its workforce on sports technical roles. For example, in 2015 , UK Sport allocated almost $70 \%$ of its full-time employees on technical roles supporting Olympic and Paralympic medal success, hosting major sporting events, developing international sporting relations, and driving governance of NGBs (DCMS, 2015b). As a result, UK Sport has been capable of better providing expertise and services to the British NGB's.

"g" and "h": As the Brazilian organization does not have a strategic planning, SNEAR faces an issue of lack of strategic focus in terms of NGB's funding criteria. The random investments in athletes of non-Olympic/Paralympic sports may negatively affect the Brazilian results in Olympic/Paralympic Games, especially considering the already limited financial resources available for Brazilian athletes with the potential of obtain medals in Olympic and Paralympic Games. The strict investment rules of UK Sport should be, at least, analysed by SNEAR. 
These comparisons between UK Sport and SNEAR reveal governance shortcomings in the Brazilian organization and provide some successful examples from the British case. Even having relevant financial resources, the lack of strategic planning of SNEAR creates a scenario in which its resources are not invested in the best way possible (Soares et al., 2016). In line with Mazzei et al. (2015), the governance issues of SNEAR impact on its elite sports national policy, affecting its guidance role as leader of the public policy for elite sports in the country. Nowadays, at the national level, several sporting organizations have been sharing the responsibility of leading the national high-performance policy in Brazil (Meira, Bastos \& Böhme, 2012; Mazzei et al., 2015).

\section{Conclusion}

This study aimed to analyse the British high-performance agency, named UK Sport, offering a detailed look at governance elements and their evolution. The data from UK Sport showed approaches, practices, and strategies that may serve as successful parameters to Brazil, especially to its public entity SNEAR.

Mostly influenced by the Olympic and Paralympic Games of 2012, UK Sport has rapidly evolved into a more professional organization. Its professional evolution was guided by complementary governance aspects, that is, more and better-qualified staff members, a "business-like" Board composition, a new organizational structure, transparent recruitment processes, more financial resources available, and investments being made through clear strategic goals and criteria. Additionally, the lasting administrations leading UK Sport (especially Chairmen and CEOs) have provided the necessary stability to implement the changes over the years.

The study also presented some points that may help SNEAR to improve its governance practices. Especially, it would be a relevant first step to publish its strategic planning (business plan), using as an example the UK Sport WCP strategical focus, with no non-Olympic/Paralympic athletes and sports and fewer Olympic/Paralympic athletes and sports being financially supported. Moreover, SNEAR can have its strategies and practices improved with technical panels supporting its decision-making processes and a more diverse administration in terms of gender equity. In addition, the UK Sport Board, with a sporting and "business-like" composition and strategically guiding investments, should be taken by SNEAR as an example of a fast and cheap initiative to improve its own governance.

In terms of strategic investments, the criteria and sporting goals of the WCP have significantly contributed to the improvement of the British sporting results in the Olympic and Paralympic Games. Certainly, in scenarios of limited financial resources, a focus on Olympic/Paralympics sports and athletes with clear medal potential may be the best option when the objective is an optimal performance in these events. Nonetheless, it is difficult to assess strategies and organizational arrangements in public institutions due to different political systems and contexts (Bayle \& Robinson, 20017). Furthermore, comparisons of financial resources spent in different countries are difficult exercises insofar as they depend on what each country considers as a priority in their sports policies (Mazzei et al., 2015). Undoubtedly, SNEAR has been supporting the recent improvement of Brazil in major sports events. However, it is crucial that its sports policy become more a real state responsibility than continuing as "political actions" (Mazzei et al., 2015).

Regarding the necessity of more full-time sports analysts (civil servants) and a betterqualified in-house workforce, SNEAR presents more legal and contextual limitations compared to UK Sport, a fact that creates a debate about what would be the most effective

PODIUM Sport, Leisure and Tourism Review | São Paulo | v. 9 | n. 1 | p. 42-70 | Jan./Apr. 2020 
elite-sports system for Brazil. The British case can be an example to re-build the Brazilian national elite sports system, particularly considering that only financial resources are not capable of creating sporting potencies (Silva, 2015a). In this way, in line with Ferkins, Mcdonald, and Shilbury (2010), SNEAR could evaluate itself and propose changes in key elements of governance, such as policy, operations, compliance, and board performance.

To sum up, hosting multi-sport events such as the Olympics can improve the methods of public administrations (Tavakkoli, 2016), being, at least, an indirect legacy (Mesquita \& Mazzei, 2015) and a unique opportunity to develop elite sports in a country (Coakley \& Souza, 2015). Therefore, Brazil should observe the British case, especially the evolution of the governance aspects of UK Sport, to better deliver its elite sports policy and use of the Olympic/Paralympic legacies.

\subsection{Limitations}

This paper only observed published information about UK Sport and SNEAR, in which hidden contextual elements could have supported a better-developed analysis. In addition, a qualitative analysis is influenced by the researcher's personal bias (Sadovnik, 2007). Other method designs and sources are crucial to further observe the cases of the British and Brazilian organizations. Moreover, this paper offered a non-exhaustive analysis of the policies, practices, and legal context of the organizations, especially SNEAR. Therefore, future studies may use this study as a starting point for deeper analysis.

\section{References}

Agência Estado. (2007). Djan Madruga assume secretaria de Alto Rendimento. Retrieved from http://atarde.uol.com.br/esportes/noticias/1014706-djan-madruga-assume-secretariade-alto-rendimento

Ahmed, M., Leahy, J., \& Pearson, S. (2016). The new sporting superpower. Retrieved from https://www.ft.com/content/e91184a4-67fa-11e6-a0b1-d87a9fea034f

Alvarez R. (2011). Governo federal tem ministério com até $70 \%$ de cargos comissionados. Retrieved from https://oglobo.globo.com/politica/governo-federal-tem-ministerio-com-ate70-de-cargos-comissionados-2792971

Babbie, E. (2007). The Basics of Social Research. Cengage Learning.

Bayle E., \& Robinson L. (2007). A Framework for Understanding the Performance of National Governing Bodies of Sport. European Sport Management Quarterly. 7 (3): 249268.

BBC Sport (2020). Tokyo 2020: UK Sport performance director Chelsea Warr quits six months before Games. Retrieved from https://www.bbc.com/sport/olympics/51127977

BBC Sport. (2016). Medal Table - Rio 2016 - Olympic Games. Retrieved from http://www.bbc.com/sport/olympics/rio-2016/medals/countries/great-britain-and-northernireland\#great-britain-and-northern-ireland

Bramham P., Hylton K., Nesti M., \& Jackson D. (2001). Sports Development: Policy, Process and Practice. London: Taylor \& Francis Group Plc.

Caemmerer, B., \& Marck, M. (2009). The Impact of Isomorphic Pressures on the Development of Organisational Service Orientation in Public Services. Retrieved from http://www.duplication.net.au/ANZMAC09/papers/ANZMAC2009-041.pdf 
Castro, S., Poffo, B., \& Souza, D. (2016). O financiamento do esporte de alto rendimento no Brasil: uma análise do programa "Brasil no Esporte de Alto Rendimento" (2004-2011). Rev Bra de Ciência e Movimento. 24(3): 146-157.

Cavalcanti, E., \& Santana, R. (2014). A importância das finanças públicas equilibradas para o desenvolvimento econômico de um país. Retrieved from http://www.gestaouniversitaria.com.br/artigos/a-importancia-das-financas-publicasequilibradas-para-o-desenvolvimento-economico-de-um-pais

CGU - Controladoria Geral da União. (2017). Relatório de Auditoria Anual de Contas. Retrieved from https://auditoria.cgu.gov.br/download/9906.pdf

Coakley. J, \& Souza, D. (2015). Legados de megaeventos esportivos: considerações a partir de uma perspectiva crítica. Rev Bra de Edu Física e Esporte. 29(4): 675-686.

Costa, G. (2019, May 16). Em crise política e financeira, esporte vive bom momento e prevê recorde em Tóquio. https://globoesporte.globo.com/blogs/brasil-emtoquio/post/2019/05/16/em-crise-politica-e-financeira-esporte-vive-bom-momento-e-preverecorde-em-toquio.ghtml

Cruz J. (2015). Ministério do Esporte esvazia cargos técnicos para contemplar amigos de fé. Retrieved from https://josecruz.blogosfera.uol.com.br/2015/07/ministerio-do-esporteesvazia-cargos-tecnicos-para-contemplar-amigos-de-fe/

DCMS - Department for Culture, Media and Sport. (2015a). The Triennial Review of UK Sport and Sport England: Annexes to Main Report. Retrieved from https://www.gov.uk/government/uploads/system/uploads/attachment_data/file/461025/Ann exes_to_triennial_review_of_UK_Sport_and_Sport_England_for_publication_NEW.pdf

DCMS - Department for Culture, Media and Sport. (2015b). The triennial review of UK Sport and Sport England. Retrieved from https://www.gov.uk/government/publications/uk-sportand-sport-england-triennial-review-report

De Bosscher, V., Bingham, J., Shibli, S., Van Bottenburg, M., \& Knop, P. (2008). The Global Sporting Arms Race: An International Comparative Study on Sports Policy Factors Leading to International Sporting Success. Aachen: Meyer \& Meyer.

De Bosscher, V., Shibli, S., Westerbeek, H., \& Van Bottenburg, M. (2015). Successful elite sport policies: an international comparison of the sports Policy Factors Leading to International Sporting Success (SPLISS 2.0) in 15 nations. London: Meyer \& Meyer Sport.

DiMaggio, P., \& Powell, W. (1983). The Iron Cage Revisited: Institutional Isomorphism and Collective Rationality in Organizational Fields. American Sociological Review. 48 (2): 147

Dowling, M., Brown, P., Legg, D., \& Beacom, A. (2017). Living with imperfect comparisons: The challenges and limitations of comparative Paralympic sport policy research. Sport Management Review, 21 (2), 101-113. https://doi.org/10.1016/j.smr.2017.05.002

Eisenhardt, K. (1989). Building Theories from Case Study Research. The Academy of Management Review, 14 (4), 532-550. http://www.jstor.org/stable/258557

Eisenhardt, K., \& Graebner, M. (2007). Theory Building from Cases: Opportunities and Challenges. The Academy of Management Journal, 50 (1), 25-32. https://www.jstor.org/stable/20159839

Estadão (2020). Conheca Marcelo Magalhaes, novo Secretario do Esportes do Governo Bolsonaro. Retrieved from https://esportes.estadao.com.br/noticias/geral,conheca-marcelomagalhaes-novo-secretario-do-esportes-do-governo-bolsonaro,70003214287

Estadão. (2015). Ricardo Leyser é nomeado novo secretário-executivo do ministério do Esporte. Retrieved from http://esportes.estadao.com.br/noticias/geral,ricardo-leyser-enomeado-novo-secretario-executivo-do-ministerio-do-esporte, 1628398 
UK Sport organizational evolution: governance aspects, Olympic and Paralympic Games influence and insights for Brazil

Ferkins, L., McDonald, G., \& Shilbury, D. (2010). A Model for Improving Board Performance: The Case of a National Sport Organisation. Journal of Management \& Organization. 16 (4): 601-621.

Folha Online (2003). Ex-jogadora de basquete Paula deixa a Secretaria Nacional de Esporte. http://www1.folha.uol.com.br/folha/esporte/ult92u66915.shtml

Gil, A. (1999). Métodos e técnicas de pesquisa social. 5. ed. Atlas.

Globo Esporte. (2016). Ministro anuncia nadador Luiz Lima como secretário de Alto Rendimento. Retrieved from http://globoesporte.globo.com/olimpiadas/noticia/2016/06/ministro-anuncia-nadador-luizlima-como-secretario-de-alto-rendimento.html

Globo Esporte. (2019). Giacomini é o novo secretário de Alto Rendimento do Ministério do Esporte. Retrieved from https://globoesporte.globo.com/olimpiadas/noticia/giacomini-e-onovo-secretario-de-alto-rendimento-do-ministerio-do-esporte.ghtml

Green, M. (2004). Changing policy priorities for sport in England: The emergence of elite sport development as a key policy concern. Leisure Studies, 23 (4), 365-385.

Green, M., \& Houlihan, B. (2005). Elite Sport Development: Policy Learning and Political Priorities. London: Routledge.

Green, M., \& Oakley, B. (2001). Elite sport development systems and playing to win: uniformity and diversity in international approaches. Leisure Studies, 20, 247-267. https://doi.org/10.1080/02614360110103598

Hantrais, L. (1999). Contextualization in cross-national comparative research. International Journal of Social Research Methodology, 2(2), 93-108. https://doi.org/10.1080/136455799295078

Harris, S., \& Houlihan, B. (2016). Implementing the community sport legacy: the limits of partnerships, contracts and performance management. European Sport Management Quarterly, 16 (4), 433-458. DOI: 10.1080/16184742.2016.1178315

Henry, I. P., Amara, A., Al-Tauqi, M., \& Lee, P. C. (2005). A typology of approaches to comparative analysis of sports policy. Journal of Sport Management, 19(4), 480-496. DOI: 10.1123/jsm.19.4.480

Herman, R., \& Renz, D. (2000). Board Practices of Especially Effective and Less Effective Local Nonprofit Organizations. The American Review of Public Administration, 30 (2), 146-160.

Houlihan, B. (2009). Mechanisms of international influence on domestic elite sport policy. International Journal of Sport Policy and Politics, 1 (1), 51 - 69. http://www.tandfonline.com/10.1080/19406940902739090

Houlihan, B., \& Green, M. (2008). Comparative Elite Sport Development, Systems, Structures and Public Policy. London: Elsevier.

Houlihan, B., \& Green, M. (2009). Modernization and sport: the reform of Sport England and UK Sport. Public Administration, 87 (3), 678 - 698.

Houlihan, B., \& Zheng, J. (2013). The Olympics and elite sport policy: where will it all end? International Journal of the History of Sport, 30, 338-355.

https://doi.org/10.1080/09523367.2013.765726

iG São Paulo. (2015). Ricardo Leyser, exonerado terça-feira, volta à Secretaria de Alto Rendimento. Retrieved from http://esporte.ig.com.br/olimpiadas/2015-11-18/ricardo-leyserexonerado-terca-feira-volta-a-secretaria-de-alto-rendimento.html

Jardim, C. (2011a). Benchmarking no setor público - resultados e fatores de sucesso: estudo comparativo de replicações de uma experiência premiada no Concurso Inovação na 
Gestão Pública Federal. Retrieved from http://bdm.unb.br/bitstream/10483/3573/1/2011_ClaudioRafaelArmijosJardim.pdf

Jardim, R. (2011b). Benchmarking na gestão publica: fácil e necessário. Retrieved from http://www.jornalopcao.com.br/colunas/contradicao/benchmarking-na-gestao-publica-facile-necessario

Jorge T. (2016). Secretário garante normalização do Bolsa Atleta e descarta novo atraso. Retrieved from http://globoesporte.globo.com/olimpiadas/noticia/2016/01/secretariogarante-normalizacao-do-bolsa-atleta-e-descarta-novo-atraso.html

JusBrasil (2019). Página 2 da Seção 2 do Diário Oficial da União (DOU) de 23 de Abril de 2019. Retrieved from https://www.jusbrasil.com.br/diarios/238038571/dou-secao-2-23-042019-pg-2

Legg, D., Fay, T., Wolff, E., \& Hums, M. (2015). The International Olympic Committee International Paralympic Committee Relationship: Past, Present, and Future. Journal of Sport and Social Issues, 39(5), 371-395. https://doi.org/10.1177/0193723514557822

Linkedin. (2019). Chelsea Warr. Retrieved from https://www.linkedin.com/in/chelsea-warr$8942632 \mathrm{~b} /$

Lodge, M. (2007). Comparative Public Policy. In Fischer, F., Miller, G. J., \& Sidney, M. S. (Eds.), Handbook of public policy analysis: theory, politics, and methods, 273-288. CRC Press. https://ebookcentral-proquestcom.libraryproxy.griffith.edu.au/lib/griffith/detail.action?docID=283245

Mackay, D. (2015). UK Sport "no compromise" to be softened following public review. Retrieved from http://www.insidethegames.biz/articles/1026231/uk-sport-no-compromiseto-be-softened-following-public-review

Mazzei, L., Meira, T., Bastos, F., Böhme, M., \& De Bosscher, V. (2015). High performance sport in Brazil: Structure and policies comparison with the international context. Gestión y Política Pública, 83-111.

ME - Ministério do Esporte. (2007). Ministério do Esporte - Concursos. Retrieved from http://www.esporte.gov.br/index.php/institucional/o-ministerio/concursos

ME - Ministério do Esporte. (2011). Goiânia vai sediar competições de futevôlei. Retrieved from http://esporte.gov.br/index.php/noticias/24-lista-noticias/39733-goiania-vai-sediarcompeticoes-de-futevolei

ME - Ministério do Esporte. (2013). Regulamentação da Lei Pelé é publicada no Diário Oficial da União. Retrieved from http://www2.esporte.gov.br/ascominternet/ascom/noticiaDetalhe.jsp?idnoticia=10284

ME - Ministério do Esporte. (2016). Departamentos - SNEAR. Retrieved from http://www.esporte.gov.br/index.php/institucional/alto-rendimento/departamentos

ME - Ministério do Esporte. (2017a). Conselho Nacional do Esporte - Resoluções. Retrieved from http://www.esporte.gov.br/index.php/institucional/o-ministerio/conselho-nacional-doesporte/resolucoes

ME - Ministério do Esporte. (2017b). Conselho Nacional do Esporte. Retrieved from http://www.esporte.gov.br/index.php/institucional/o-ministerio/conselho-nacional-doesporte/comissoea

ME - Ministério do Esporte. (2017c). Legislação e Documentos. Retrieved from http://www.esporte.gov.br/index.php/institucional/o-ministerio/conselho-nacional-doesporte/legislacao-e-documentos

ME - Ministério do Esporte. (2017d). Missão - SNEAR. Retrieved from http://www.esporte.gov.br/index.php/institucional/alto-rendimento/missao 
UK Sport organizational evolution: governance aspects, Olympic and Paralympic Games influence and insights for Brazil

ME - Ministério do Esporte. (2017e). SNEAR. Retrieved from

http://www.esporte.gov.br/index.php/institucional/alto-rendimento

ME - Ministerio do Esporte. (2018). Relatório de Gestão do Exercício 2017. Retrieved from http://www.esporte.gov.br/arquivos/RG_2017_FINAL.pdf

Meira, T., \& Bastos, F. (2011). Estruturas de Organização e Promoção Esportiva. In Maria Tereza Silveira Böhme (ed.), Esporte Infantojuvenil: Treinamento a Longo Prazo e Talento Esportivo. São Paulo: Phorte.

Meira, T., Bastos, F., \& Böhme, M. (2012). Análise da estrutura organizacional do esporte de rendimento no Brasil: um estudo preliminar. Revista Brasileira de Educação Física e Esporte, 26 (2), 251-62.

Mendes, A., \& Codato, A. (2015). The institutional configuration of sport policy in Brazil: organization, evolution and dilemmas. Revista da Administração Pública, 49(3), 563-593.

Mesquita, R., \& Mazzei, L. (2015). O legado dos Jogos Olímpicos da Era Moderna Reflexões sobre Megaeventos Esportivos. In: Vance P, Nassif V, Masteralexis L, organizadores. Gestão do Esporte. Rio de Janeiro: LTC, 243-262.

Mogalakwe, M. (2006). The Use of Documentary Research Methods in Social Research. African Sociological Review, 10(1), 221-230. https://www.researchgate.net/publication/267994948

Nascimento, U. (2017). Benchmarking: conhecer boas práticas e cases de sucesso como estratégia de melhoria contínua de processos e produtos. Retrieved from http://www.administradores.com.br/artigos/carreira/benchmarking-conhecer-boas-praticase-cases-de-sucesso-como-estrategia-de-melhoria-continua-de-processos-eprodutos/101910/

National Audit Office. (2005). UK Sport: Supporting Elite Athletes. Retrieved from https://www.nao.org.uk/wp-content/uploads/2005/01/0405182.pdf

Palmer, K. Brown, A., Evans, J., Marani, H., Russell1, K., Martin, D., Ivers, N. (2018). Qualitative analysis of the dynamics of policy design and implementation in hospital funding reform. PloS ONE, 13(1). https://doi.org/10.1371/journal.pone.0191996

Paudel, N. (2009). A Critical Account of Policy Implementation Theories: Status and Reconsideration. Nepalese Journal of Public Policy and Governance, XXV (2), 36-54. https://www.semanticscholar.org/paper/A-Critical-Account-of-Policy-Implementation\%3A-and-Paudel/96cb1a5f553dfe89767763005fa65f474af8e6d3

Pereira, B. (2015). Brasil fica com o terceiro lugar no Mundial de Balonismo. Retrieved from http://www.esporte.gov.br/index.php/radio-esporte-lista/48304-brasil-fica-com-o-terceirolugar-no-mundial-de-balonismo

Portal da Transparência. (2017a). Convênios por Órgão Concedente. Retrieved from http://www.portaltransparencia.gov.br/convenios/consultam.asp?fcod=25\&fnome=espigao $+\mathrm{d} \% 27$ oeste $\&$ fuf $=$ ro \&festado $=$ rondonia $\&$ forgao $=51000 \&$ fnomeorgao $=$ ministerio $\% 20 \mathrm{do} \%$ 20esporte \&fconsulta $=1$

Portal da Transparência. (2017b). Convênios por Órgão Concedente. Retrieved from http://www.portaldatransparencia.gov.br/convenios/consultam $\cdot$ asp?fcod=7107\&fnome $=$ sao + paulo\&festado $=$ sp \&forgao $=00 \&$ fconsulta $=0$

Portal da Transparência. (2017c). Convênios por Órgão Concedente. Retrieved from http://www.portaldatransparencia.gov.br/convenios/DetalhaConvenio.asp?CodConvenio=8 02416\&TipoConsulta $=1 \&$ UF $=$ pe $\&$ CodMunicipio $=2457 \&$ CodOrgao $=51000 \&$ Pagina $=\&$ Per iodo=

Portal da Transparência. (2017d). Convênios por Órgão Concedente. Retrieved from https://www.portaldatransparencia.gov.br/convenios/DetalhaConvenio.asp?CodConvenio= 
609021\&TipoConsulta $=1 \&$ UF=CE $\&$ CodMunicipio $=\&$ CodOrgao $=51000 \&$ Pagina $=\&$ Period $\mathrm{O}=$

Pussieldi, A. (2016). Luiz Lima é o novo Secretário Nacional de Esportes do Ministério do Esporte. Retrieved from http://sportv.globo.com/site/blogs/especial-blog/blog-docoach/post/luiz-lima-e-o-novo-secretario-nacional-de-esportes-do-ministerio-doesporte.html

Redação Pragmatismo. (2015). Aparelhamento evangélico no Ministério dos Esportes. Retrieved from https://www.pragmatismopolitico.com.br/2015/05/o-aparelhamentoevangelico-no-ministerio-dos-esportes.html

Roan, D. (2017). UK Sport: Funding policy could be reconsidered. Retrieved from http://www.bbc.com/sport/olympics/29791277

Robinson, L. (2004). Managing Public Sport and Leisure Services. London: Taylor \& Francis Group Plc.

Rubio, V. (1999). Introdução ao projeto de pesquisa científica. Vozes.

Sarmento, J., \& Carvalho, M. (2015). A gestão esportiva na Europa e em Portugual. In: Vance, P., Nassif, V., \& Masteralexis, L. Gestão do Esporte. Rio de Janeiro: LTC, 291307.

Scottish Disability Sport. (2016). BPA Unveils Tim Hollingsworth as New Chief Executive. Retrieved from http://www.scottishdisabilitysport.com/sds/index.cfm/news/latestnews1/bpa-unveils-tim-hollingsworth-as-new-chief-executive/

SEE - Secretaria Especial de Esportes (2020a). Quem é Quem. Retrieved from http://arquivo.esporte.gov.br/index.php/institucional/o-ministerio/57716-quem-e-quem

SEE - Secretaria Especial de Esportes (2020b). Conselho Nacional do Esporte - Comissões. Retrieved from https://esporte.gov.br/secretaria/cne/conselho-nacional-doesporte/comissoes

SEE - Secretaria Especial de Esportes (2020c). Conselho Nacional do Esporte. Retrieved from https://esporte.gov.br/secretaria/cne/conselho-nacional-do-esporte

Silva, D., Borges, C., \& Amaral, S. (2015). Gestão das políticas públicas do Ministério do Esporte do Brasil. Revista Brasileira de Educação Física e Esporte, 29(1), 65-79.

Silva, M. (2015a). Apresentação. In: Vance, P., Nassif, V., \& Masteralexis, L. Gestão do Esporte. Rio de Janeiro: LTC, ix-x.

Silva, O. (2015b). Carlos Geraldo é o novo secretário de Alto Rendimento. Retrieved from http://bpossesiosilva.blogspot.com.br/2015/04/ministerio-do-esporte-carlos-geraldo-e.html

SNEAR - Secretaria Nacional de Esporte de Alto Rendimento. (2019). Institucional. Retrieved from http://www.esporte.gov.br/index.php/institucional/alto-rendimento

SNEAR (2020). Alto Rendimento. Retrieved from https://esporte.gov.br/secretaria/secretariasnacionais/alto-rendimento

Soares, J., Antunes, H., Bárbara, A., Escórcio, C., \& Saldanha, P. (2016). The public interest of sports at non-profit sports organizations that are supported by the government. Rev Bra de Edu Física e Esporte, 30(3), 689-702.

Sracklen, K., Hylton, K., \& Long, J. (2006). Managing and monitoring equality and diversity in UK sport an evaluation of the sporting equals racial equality standard and its impact on organizational change. Journal of Sport \& Social Issues, 30 (3), 289-305.

Tavakkoli, M. (2016). Leveraging of the Olympic Games on Mega-Sporting Events: A Strategic Framework for the Development of Sport. American Journal of Sports Science and Medicine, 4(3), 44-56.

TCU - Tribunal de Contas da União. (2011). Relatório de Auditoria Operacional: Esporte de Alto Rendimento. Brasília: TCU, 1-90. 
UK Sport organizational evolution: governance aspects, Olympic and Paralympic Games influence and

Terra. (2017). Rogério Sampaio assume secretaria do Ministério do Esporte. Retrieved from https://www.terra.com.br/esportes/rogerio-sampaio-assume-secretaria-do-ministerio-doesporte,5434ce05ed8e98e3a9c7d276ac5d8b7bu7lwkny4.html

Theodoraki, E. (1999). The making of the UK Sports Institute. Managing Leisure, 4, 187200. DOI:10.1080/136067199375742

Tricker R. (1984). Corporate governance. London: Gower.

UK Sport. (2001a). United Kingdom Sports Council Financial Statements for the Year Ended 31st March 2001 - Exchequer. Retrieved from http://www.uksport.gov.uk/resources/annual-reports

UK Sport. (2001b). United Kingdom Sports Council Financial Statements for the Year Ended 31st March 2001 - Lottery. Retrieved from http://www.uksport.gov.uk/resources/annualreports

UK Sport. (2002a). United Kingdom Sports Council Financial Statements for the Year Ended 31 st March 2002 - Exchequer. Retrieved from http://www.uksport.gov.uk/resources/annual-reports

UK Sport. (2002b). United Kingdom Sports Council Financial Statements for the Year Ended 31 st March 2002 - Lottery. Retrieved from http://www.uksport.gov.uk/resources/annualreports

UK Sport. (2003a). United Kingdom Sports Council Financial Statements for the Year Ended 31 st March 2003 - Exchequer. Retrieved from http://www.uksport.gov.uk/resources/annual-reports

UK Sport. (2003b). United Kingdom Sports Council Financial Statements for the Year Ended 31 st March 2003 - Lottery. Retrieved from http://www.uksport.gov.uk/resources/annualreports

UK Sport. (2004a). United Kingdom Sports Council Financial Statements for the Year Ended 31 st March 2004 - Exchequer. Retrieved from http://www.uksport.gov.uk/resources/annual-reports

UK Sport. (2004b). United Kingdom Sports Council Financial Statements for the Year Ended 31 st March 2004 - Lottery. Retrieved from http://www.uksport.gov.uk/resources/annualreports

UK Sport. (2004c). Keen Joins UK Sport as Performance Adviser. Retrieved from http://uksport.gov.uk/news/2004/02/17/keen-joins-uk-sport-as-performance-adviser

UK Sport. (2005a). United Kingdom Sports Council Financial Statements for the Year Ended 31 st March 2005 - Exchequer. Retrieved from http://www.uksport.gov.uk/resources/annual-reports

UK Sport. (2005b). United Kingdom Sports Council Financial Statements for the Year Ended 31 st March 2005 - Lottery. Retrieved from http://www.uksport.gov.uk/resources/annualreports

UK Sport. (2005c). UK Sport Appoints John Steele as New Chief Exec. Retrieved from http://uksport.gov.uk/news/2005/05/27/uk-sport-appoints-john-steele-as-new-chief-exec

UK Sport. (2006a). New Structure for High Performance Sport. Retrieved from http://uksport.gov.uk/news/2006/04/06/new-structure-for-high-performance-sport

UK Sport. (2006b). UK Sport Announce Additions to Performance Directorate. Retrieved from http://uksport.gov.uk/news/2006/11/28/uk-sport-announce-additions-to-performancedirectorate

UK Sport. (2007). Grant-in-Aid and Lottery Distribution Fund Report and Accounts for the Year Ended 31 March 2007. Retrieved from http://www.uksport.gov.uk/resources/annualreports 
UK Sport. (2008). Grant-in-Aid and Lottery Distribution Fund Report and Accounts for the Year Ended 31 March 2008. Retrieved from http://www.uksport.gov.uk/resources/annualreports

UK Sport. (2009). Grant-in-Aid and Lottery Distribution Fund Report and Accounts for the Year Ended 31 March 2009. Retrieved from http://www.uksport.gov.uk/resources/annualreports

UK Sport. (2010). Grant-in-Aid and Lottery Distribution Fund Report and Accounts for the Year Ended 31 March 2010. Retrieved from http://www.uksport.gov.uk/resources/annualreports

UK Sport. (2011a). Grant-in-Aid and Lottery Distribution Fund Report and Accounts for the Year Ended 31 March 2011. Retrieved from http://www.uksport.gov.uk/resources/annualreports

UK Sport. (2011b). Vanessa Wilson Appointed Director of Commercial and Communications. Retrieved from http://uksport.gov.uk/news/2011/10/06/vanessa-wilson-appointed-directorof-commercial-and-communications

UK Sport. (2012a). Grant-in-Aid and Lottery Distribution Fund Report and Accounts for the Year Ended 31 March 2012. Retrieved from http://www.uksport.gov.uk/resources/annualreports

UK Sport. (2012b). Timson Appointed Director of Performance at UK Sport. Retrieved from http://uksport.gov.uk/news/2012/10/17/timson-appointed-director-of-performance-at-uksport

UK Sport. (2013). Grant-in-Aid and Lottery Distribution Fund Report and Accounts for the Year Ended 31 March 2013. Retrieved from http://www.uksport.gov.uk/resources/annualreports

UK Sport. (2014). Grant-in-Aid and Lottery Distribution Fund Report and Accounts for the Year Ended 31 March 2014. Retrieved from http://www.uksport.gov.uk/resources/annualreports

UK Sport. (2015a). Grant-in-Aid and Lottery Distribution Fund Report and Accounts for the Year Ended 31 March 2015. Retrieved from http://www.uksport.gov.uk/resources/annualreports

UK Sport. (2015b). World Class Programme. Retrieved from http://www.uksport.gov.uk/ourwork/world-class-programme

UK Sport. (2015c). English Institute of Sport. Retrieved from http://www.uksport.gov.uk/about-us/the-english-institute-of-sport

UK Sport. (2015d). UK Sport Structure. Retrieved from http://www.uksport.gov.uk/aboutus/uk-sport-structure

UK Sport. (2015e). Jobs in Sport. Retrieved from http://www.uksport.gov.uk/jobsinsport?uksp=1

UK Sport. (2015f). Panels. Retrieved from http://www.uksport.gov.uk/about-us/panels

UK Sport. (2015g). Swimming Teacher. Retrieved from http://uksport.gov.uk/jobsinsport/Swimming-Teacher-UKSP-4882

UK Sport. (2015h). FAQs. Retrieved from http://www.uksport.gov.uk/about-us/board

UK Sport. (2016a). UK Sport News. Retrieved from http://www.uksport.gov.uk/news

UK Sport. (2016b). Grant-in-Aid and Lottery Distribution Fund Annual Report and Accounts for the year ended 31 March 2016. Retrieved from http://www.uksport.gov.uk/resources/annual-reports

UK Sport. (2016c). How UK Sport Funding Works. Retrieved from http://www.uksport.gov.uk/our-work/investing-in-sport/how-uk-sport-funding-works 
UK Sport organizational evolution: governance aspects, Olympic and Paralympic Games influence and insights for Brazil

UK Sport. (2017a). Performance Investment Policy Review. Retrieved from http://www.uksport.gov.uk/resources/strategic-review

UK Sport. (2017b). Grant-in-Aid and Lottery Distribution Fund Annual Report and Accounts for the year ended 31 March 2017. Retrieved from https://www.uksport.gov.uk/resources/annual- reports

UK Sport. (2017c). Historical Funding Figures. Retrieved from http://www.uksport.gov.uk/our-work/investing-in-sport/historical-funding-figures

UK Sport. (2018). Grant-in-Aid and Lottery Distribution Fund Annual Report and Accounts for the year ended 31 March 2018. Retrieved from https://www.uksport.gov.uk/resources/annual-reports

UK Sport. (2019a). News. Retrieved from http://www.uksport.gov.uk/news

UK Sport. (2019b). UK Sport appoints new Director of Performance to maintain momentum after Rio 2016. Retrieved from http://www.uksport.gov.uk/news/2016/07/28/uk-sportappoints-warr-as-director-of-performance

UK Sport (2019c). Grant-in-Aid and Lottery Distribution Fund Annual Report and Accounts for the year ended 31 March 2019. Retrieved from https://www.uksport.gov.uk/resources/annual-reports

UK Sport (2020). UK Sport Structure. Retrieved from https://www.uksport.gov.uk/ourwork/about-us/uk-sport-structure

UOL. (2004). Quadro de medalhas das Olimpíadas de Atenas. Retrieved from http://olimpiadas.uol.com.br/2008/historia/2004/medalhas.jhtm

Vecchioli, D. (2017). Em crise, Ministério se oferece para levar 90 do jiu-jítsu a Abu Dhabi por $R \$ 1,5 \mathrm{mi}$. Retrieved from https://olharolimpico.blogosfera.uol.com.br/2017/04/17/ministerio-esporte-jiu-jitsu/

Vecchioli, D. (2018). 'Nova Lei Piva' discute como dividir quase $R \$ 1$ bilhão ao ano no esporte. Retrieved from https://olharolimpico.blogosfera.uol.com.br/2018/05/29/nova-leipiva-discute-como-dividir-quase-r-1-bilhao-ao-ano-no-esporte/

Vecchioli, D. (2019a). COB prevê repasse recorde a confederações em 2020. Retrieved from https://olharolimpico.blogosfera.uol.com.br/2019/10/30/cob-preve-repasse-recorde-aconfederacoes-em-2020/

Vecchioli, D. (2019b). Governo anuncia Bolsa Pódio, mas não sabe até quando vai pagar atletas. Retrieved from https://olharolimpico.blogosfera.uol.com.br/2019/12/05/governoanuncia-bolsa-podio-mas-nao-sabe-ate-quando-vai-pagar-atletas/

Vecchioli, D. (2019c). Esporte deve sair do Ministério da Cidadania, mas não sabe para onde. Retrieved from https://olharolimpico.blogosfera.uol.com.br/2019/11/16/esporte-devesair-do-ministerio-da-cidadania-mas-nao-sabe-para-onde/

Vecchioli, D. (2019d). Governo abre edital e dá oito dias para inscrições no Bolsa Atleta. Retrieved from https://olharolimpico.blogosfera.uol.com.br/2019/10/25/governo-abreedital-e-da-oito-dias-para-inscricoes-no-bolsa-atleta/

Vecchioli, D. (2019e). Governo Bolsonaro reduz investimento em esporte militar. Retrieved from https://olharolimpico.blogosfera.uol.com.br/2019/10/13/governo-bolsonaro-reduzinvestimento-em-esporte-militar/

Vecchioli, D. (2019f). Governo atrasa edital e não tem recursos para novo Bolsa Atleta. Retrieved from https://olharolimpico.blogosfera.uol.com.br/2019/10/11/governo-atrasaedital-e-nao-tem-recursos-para-novo-bolsa-atleta/

Vecchioli, D. (2019g). Proposta de orçamento para 2020 corta $49 \%$ do investimento no esporte. Retrieved from https://olharolimpico.blogosfera.uol.com.br/2019/09/26/propostade-orcamento-para-2020-corta-49-do-investimento-no-esporte/ 
Vimarlund, V., \& Keller, C. (2014). The many Faces of Implementation. Vinnova Report, Ministry of Enterprise, Energy and Communications/Jönköping International Business School. https://publector.org/uploads/publications/The-many-Faces-ofImplementation/vr_14_06.pdf

Yin, R.K. (1984). Case Study Research: Design and Methods. Beverly Hills: Sage.

Zainal, Z. (2007). Case study as a research method. Jurnal Kemanusiaan, 9, 1-6.

Zardini Filho, C.E., Smith, A., Walters, A. \& Chiotis, S. (2018). Sport public finance: a UK Sport analysis. Lecturas: Educación Física y Deportes, 23 (240), 16-33. 